\title{
Inflammatory Mechanisms of HCC Development
}

\author{
Maria Grazia Refolo ${ }^{1}$, Caterina Messa ${ }^{1} \mathbb{D}$, Vito Guerra ${ }^{2}{ }^{(}$, Brian Irving Carr $^{3, *}$ and \\ Rosalba D'Alessandro ${ }^{1}$
}

1 Laboratory of Cellular and Molecular Biology, Department of Clinical Pathology, National Institute of Gastroenterology, "Saverio de Bellis" Research Hospital, 70013 Castellana Grotte, BA, Italy; maria.refolo@irccsdebellis.it (M.G.R.); caterina.messa@irccsdebellis.it (C.M.); rosalba.dalessandro@irccsdebellis.it (R.D.)

2 Clinical Trial Unit, National Institute of Gastroenterology, "Saverio de Bellis" Research Hospital, 70013 Castellana Grotte, BA, Italy; vito.guerra@irccsdebellis.it

3 Department of Liver Cancer Biology, Liver Transplant Institute, Inonu University, Malatya 44280, Turkey

* Correspondence: brianicarr@hotmail.com; Tel.: +1-412-980-4518

Received: 26 February 2020; Accepted: 5 March 2020; Published: 10 March 2020

\begin{abstract}
HCC (hepatocellular carcinoma) is the second leading cause of cancer deaths worldwide, with several etiologic causes, mostly inflammation-associated. Different inflammatory responses in the liver can be triggered by different etiological agents. The inflammatory process can be resolved or be persistent, depending on the etiology and multiple other factors. Chronic inflammation, tissue remodeling, genetic alterations, and modifications in cellular signaling are considered to be key processes promoting immunosuppression. The progressive immunosuppression leads to the inactivation of anti-tumor immunity involved in HCC carcinogenesis and progression. Tumor cellular processes including DNA damage, necrosis, and ER (endoplasmic reticulum) stress can affect both immune-surveillance and cancer-promoting inflammation, supporting a mutual interdependence. Here, we review the current understanding of how chronic liver injury and inflammation is triggered and sustained, and how inflammation is linked to HCC. The identification of many hepatic microenvironmental inflammatory processes and their effector molecules, has resulted in extensive translational work and promising clinical trials of new immunomodulatory agents.
\end{abstract}

Keywords: cancer etiology; chronic inflammation; immunosurveillance; immunosuppression; HCC

\section{Introduction}

Several lines of evidence led to the consideration that a deregulated microenvironment might be a major factor in tumorigenesis. Chronic inflammation is associated with high incidence of several cancers [1,2]. HCC (hepatocellular carcinoma), which arises mostly in inflamed livers, represents one example of this well studied relationship. Inflammation-inducing factors include HBV (hepatitis B virus), HCV (hepatitis C virus), diabetes, obesity, excessive alcohol consumption and metabolic diseases, which contributing to fibrosis and cirrhosis are considered to be factors that predispose to HCC. In addition, specific features of the hepatic microenvironment exert selective pressure that could explain the diversity found in different types of liver cancer [3]. This review aims to consider several crucial aspects of the liver microenvironment as having a role in driving hepatocarcinogenesis and tumor survival, as well as some new therapeutic approaches deriving from this knowledge $[4,5]$, highlighting the existence of different pathways of carcinogenesis triggered by viral infections with respect to those induced by other etiologic agents. 


\section{Microenvironmental Factors in HCC}

Chronic inflammation, tissue remodeling, genetic alterations, and alterations in cellular signaling are considered to be key processes involved in HCC carcinogenesis and progression, and they are driven by liver microenvironmental factors, which in turn are modified by their mutual interdependence.

\subsection{DNA Alterations in HCC}

Each HCC tumor is to be considered as comprising a specific set of somatic mutations including genetic, epigenetic, transcriptomic and metabolic alterations that constitute its unique molecular fingerprint [6]. The spontaneous accumulation of genetic alterations in cancer cells derives from several events such as virus infections, carcinogen exposure (aflatoxin B1) and defects in DNA repair mechanisms. The first studies that identified mutations in HCC are those related to HBV infection that have highlighted the key role in the carcinogenesis process of mutations in b-catenin (CTNNB1) and TP53, occurring in $20 \%-40 \%$ and $20 \%-50 \%$ of cases, respectively [7-10]. A high frequency of specific TP53 mutations was also revealed after prolonged exposure to aflatoxin B1 [11]. Although the insertion of the HBV virus may occur randomly, it is now widely demonstrated that there are preferential insertion sites, such as TERT, MLL4, CCNE1, CCNA2, and RARB [12-15]. In some cases, the insertion is associated with the over expression of the corresponding gene [12], in others it is associated with chromosomal instability [15]. Furthermore, viral proteins may exert oncogenic activity on the mechanisms of activation of signaling pathways involved in cell growth and motility [16]. Therefore, HBV infection can determine the onset of HCC even in the absence of inflammation or cirrhosis. On the contrary, in all cases in which the carcinogenesis process takes place in a cirrhotic liver, it is difficult to establish a causal link between a given inflammatory context and the onset of specific mutations in the liver cells. This scenario is typical of HCC related to HCV, alcohol consumption, food toxins or metabolic alterations. Chronic inflammation and oxidative stress likely contribute to further accumulation of genetic alterations in hepatocytes, especially if already in a cirrhotic liver [17]. However, numerous studies have tried to identify possible driver genes even in these contexts. Considering HCV-related HCC, some studies suggested that HCV proteins may exert direct oncogenic activity by interfering with signaling cascades such as the Wnt/B-catenine, TGFB, NFKB or P53 pathway $[18,19]$. Concerning alcohol consumption acetaldehyde and reactive oxygen species metabolites may induce mutations by binding to DNA or inducing lipid peroxidation and DNA adducts respectively [20-22]. Moreover, chronic oxidative stress due to alcohol intake and cytokine release leads to chronic inflammation, cirrhosis, and progression in HCC. Interestingly, polymorphism of superoxide dismutase and MnSoD has been associated with HCC occurrence in alcohol-related cirrhosis, but not in HCV-related cirrhosis [23]. Our knowledge of the cancer genome is significantly improved thanks to genome wide sequencing using NGS (next-generation) technologies [24]. NGS has provided a comprehensive landscape of frequency of specific molecular alterations useful to better understand their molecular mechanisms and to identify the key driver genes involved in HCC pathogenesis and progression [25]. This knowledge will open up new and more effective therapeutic approaches NGS studies revealed that ARID1A and ARID2 are mutated in $15 \%$ and $10 \%$ of HCC patients, respectively [26]. ARID1A and ARID2 coding for proteins acting as tumor suppressor genes and involved in the SWI/SNF complex which plays a key role in chromatin remodeling and transcription control. In some cases, the ARID1A mutation was associated with high alcohol intake [26] as well as 6p21.1 amplification of FGF19 was described in NASH-derived HCC [27]. Other mutations, identified in KEAP1 and NFE2L2, are involved in constitutive activation of the stress oxidative signaling. Moreover, other less frequent mutations are revealed in some of the gene of the MAPK pathway such as PIK3CA, RAS and RPS6KA3 [28].

Although the improvement in the molecular analyzes of the whole genome, the identification of the possible driver genes is still incomplete. Further efforts will be needed to shed light on NAFLD (non-alcoholic fatty liver disease)/NASH (non-alcoholic steatohepatitis)-related carcinogenesis mechanisms (see also Section 2.6). The analyses conducted at the system biology level are proving to 
be of great interest. Recently, Chen and colleagues [29] carried out a bioinformatic analysis of 1074 published articles that led to the identification of 560 human genes associated with HCC. These genes are involved in gene expression, protein catabolism, DNA methylation or transcription. Through biological function enrichment analysis, they were also able to identify specific pathways closely related to hepatocarcinogenesis and involved in cellular processes such as apoptosis, necro-apotosis and cell cycle. Based on their crosstalk, these pathways could be divided into three major modules. The first module includes pathways involved in signal transmission, immunological suppression, cellular metabolism and regulation of various hormonal factors; the second module directly associates HBV and HCV viral infection with the onset of HCC; the third module includes genes with altered expression, that act synergistically in the modulation of the same biological function in various cancers. This comprehensive and systematic analysis allowed the identification of 14 genes as potential biomarkers in the diagnosis and treatment of HCC. Of great interest are the CDK2 and CDK4 that cooperate, in association with cyclin $\mathrm{E}$ and $\mathrm{D}$, in promoting the transition from phase $\mathrm{G} 1$ to phase $\mathrm{S}$ of the cell cycle. Therefore, an alteration of these genes directly affects the regulation of the cell cycle during hepatocarcinogenesis. However, TP53 modulating the CDK2-4-inhibitor CDKN1A acts as suppressor of tumorigenesis. TP53 also has an important role in inhibiting the expression of VEGFA and therefore the process of neo-angiogenesis and tumor growth. These genes have a robust "classification effectiveness", able to distinguish normal samples from tumors. The goal of this study was the identification of potential targets for the diagnosis and treatment of HCC. It is a widespread opinion that somatic insertion and/or deletion mutations involving driver genes can lead to the formation of neo-antigens. Although the presence of neo-antigens stimulates the immune system their prolonged exposure generally causes the establishment of an immune tolerant microenvironment supported by the continuous interaction between PD-1 receptor and its ligand PD-L1 leading to T cells exhaustion [30,31].

Although the lack of drugs targeting the most prevalent mutations represent a crucial limiting step [32], data derived from mutation analysis could also help to predict response to new treatments including immunotherapies, particularly immune checkpoint blockade [33], as well as molecularly-targeted inhibitors of known genetic changes occurring in HCC, such as in the FGFR (Fibroblast Growth Factor Receptor) gene amplification (Blueprint's BLU-554). Interestingly, response to anti-PD1-L1 (Programmed Death-Ligand1)-based therapies was significantly better in patients with colorectal cancer and mismatch-repair status, which was associated with a high TMB (tumor mutational burden). A high TMB is associated with an increase in neo-antigens and a consequent stimulation of the immune system [34,35]. These conditions seem to correlate with response to immune checkpoint blockade as well demonstrated in different solid tumors [36,37].

\subsection{Chronic Inflammation}

Chronic inflammation, characterized by infiltration of macrophage and immature myeloid cells and dysregulated production of cytokines, may be considered to be one of the main triggers of HCC carcinogenesis and tumor progression. In the premalignant stage, chronic activation of inflammatory signaling pathways results in the generation of ROS (reactive oxygen species) and NOS (nitrogen oxygen species). Inflammatory cells (including stromal cells) within the premalignant environment produce a vast array of cytokines, growth factors, chemokines, prostaglandins, and proangiogenic factors (Figure 1).

Altogether these molecules play a key role in creating a microenvironment that supports the transformation of hepatocytes, but also induces their survival through activation of anti-apoptotic pathways and inhibition of immune surveillance. During HBV infection, the accumulation of virus-specific CD8+ T cells and nonspecific inflammatory cells into the liver parenchyma are mediated by platelets which contain several inflammatory molecules and immune mediators, stored in intracellular granules [38]. Platelet activation recruits inflammatory cells to the site of inflammation and induces the expression of several GFs (growth factors) that mediate cellular proliferation and neo-angiogenesis (Figure 2). High levels of platelets and associated GFs detected in thrombocytosis significantly 
correlate with large size HCCs $[39,40]$. Both thrombocytosis and large tumor size are reported with a high incidence in association with portal vein thrombosis, metastasis and poor prognosis [41,42]. Platelets and PDGF (platelets derived growth factor) have been described to have a stimulatory effect on growth of normal and tumoral hepatocytes $[43,44]$. A mechanism by which platelets contribute to liver injury is their integrin-dependent adhesion to LSECs (liver sinusoidal endothelial cells), which are thus activated through NF-kB signaling. Activated LSECs secrete specific chemokines that regulate the recruitment and adhesion of leukocytes to the endothelium [45]. Furthermore, in the context of hepatitis B infection, infected hepatocytes are killed by CD8+ T cells adherent to the sinusoids in a platelet-dependent process [46].

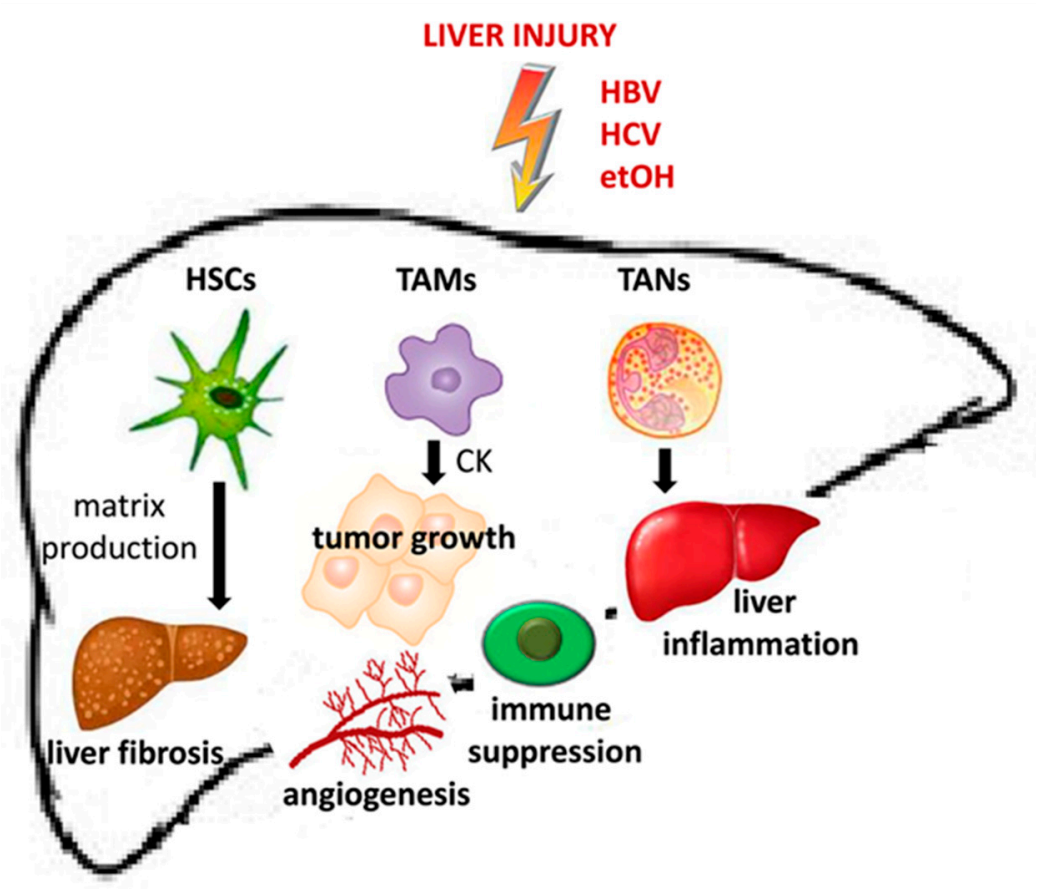

Figure 1. Role of stromal cells in the realization of premalignant microenvironment and HCC onset. HSCs (Hepatic Stellate Cells), TAMs (Tumor Associated Macrophages) and TANs (Tumor Associated Neutrophils) contribute respectively to induce liver fibrosis by matrix production, to promote tumor growth prompting the angiogenesis process and immune suppression leading to liver inflammation.

Moreover, growing data show that the modulatory actions of platelet factors such as EGF (epidermal growth factor), IGF-I (insulin-growth factor-I), TGF- $\beta$ (transforming growth factor beta), PDGF and VEGF (vascular endothelial growth factor) alter the cancer chemotherapy sensitivity or resistance [47]. Our recent results supported a primary role of EGF and IGF-I in interfering with the inhibitory action of Sorafenib and Regorafenib in HCC cell lines [48-50] (Figure 2).

As a consequence of increased proliferation of hepatocytes, shortening of telomeres and the consequent chromosomal instability was observed in 90\% of HCC carcinogenesis and progression [51]. Mechanisms of telomerase reactivation in HCC are associated to TERT promoter mutations, TERT (telomerase reverse transcriptase) amplification, chromosome translocations and HBV or adeno-associated virus type 2 insertion into the TERT promoter [51-53]. An important risk factor for the occurrence of HCC is given by the replacement of hepatocytes with liver progenitor cells that occurs following a chronic infection. The presence of pro-inflammatory cytokine such as IL-6 (Interleukin-6) enhances the transformation of the liver progenitor cells into a more cancerous phenotype [54] (Table 1).

The chronic inflammation plays also a key role in the mechanisms leading to NASH-derived HCC. Obesity or other genetic factors contribute to the development of insulin resistance and steatosis. The metabolic alterations occurring in injured hepatocytes trigger the inflammatory response mainly through the pathways activated by the Toll-like receptors. Although "senescence surveillance" 
pathways [55] (Table 1), involving p53 and N-Ras, directed to remove cancer cells are activated, other mechanisms intrinsic to the cancer cells together with microenvironmental factors may be related to immune system dysfunction. Hepatocytes actively recruit Kupffer cells as well as other components of the innate immune response through the activation of the inflammasome and the coordinated release of pro-inflammatory and pro-fibrogenic cytokines and ligands.

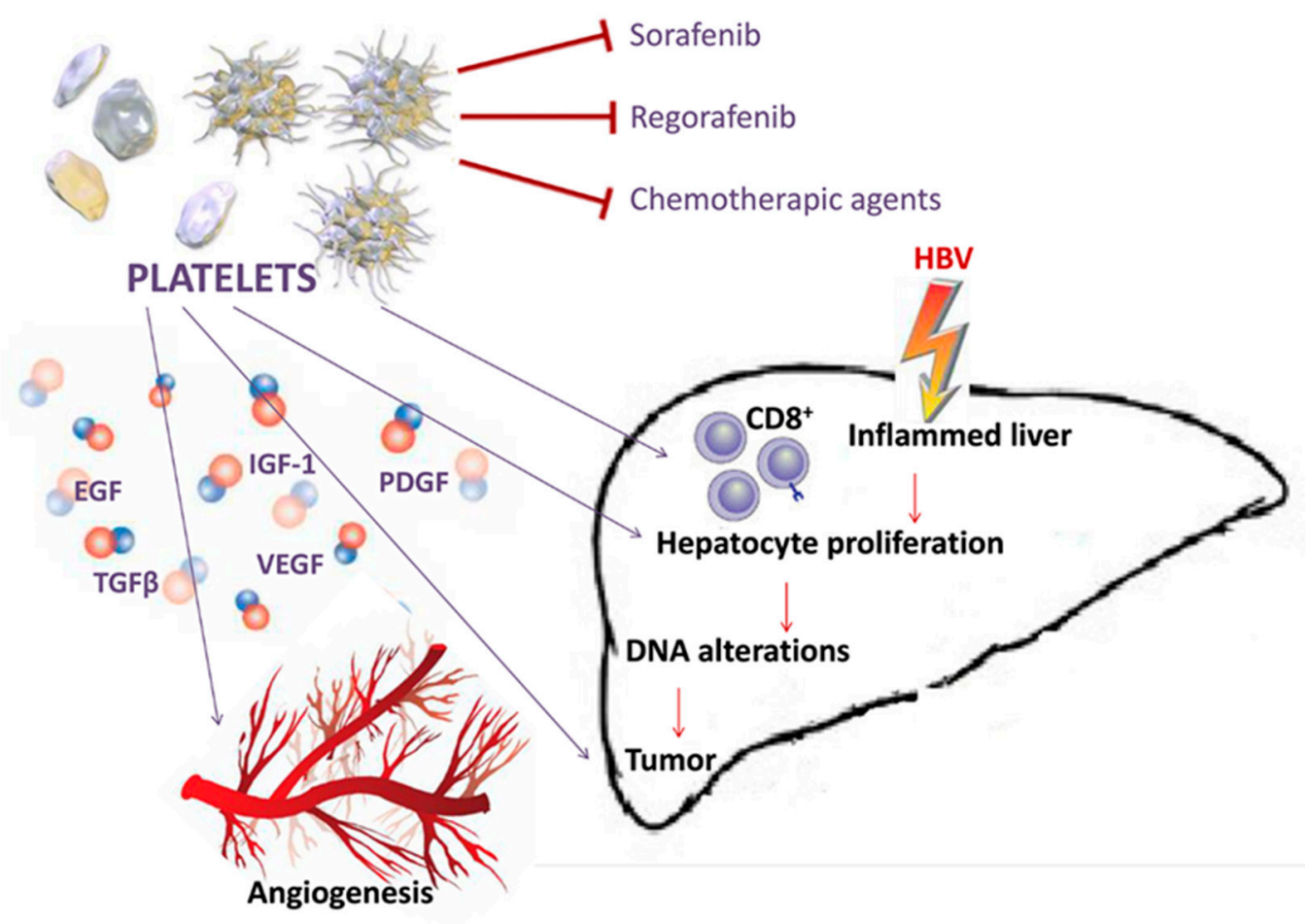

Figure 2. Platelets amplify liver damage. Growth factors released by the activated platelets can reinforce the changes induced by HBV at the level of the hepatic parenchyma as well as the formation of new vessels. Platelets create a microenvironment that opposes the action of drugs such as Sorafenib, Regorafenib and chemotherapic agents.

These considerations support the interest in the use of nonsteroidal anti-inflammatory drugs (NSAID) as potential agents to reduce chronic risk of neoplastic progression due to their anti-inflammatory properties. These drugs, especially aspirin, are able to reduce cellular growth acting on COX (cyclooxygenase) enzymatic pathways, which mediate inflammation [56]. Each category of NSAID may represent different levels of selectivity for COX isoforms and different mechanisms of action [56,57] (Table 1). Although there is growing literature concerning the role of NSAIDs in cancer prevention, the results can be contradictory. This is probably due to the poor knowledge of the molecular mechanisms underlying the beneficial or side effects of these drugs in each type of cancer, including HCC [58].

Table 1. Experimental evidence linking inflammation to HCC development.

\begin{tabular}{crc}
\hline Animal Model & Results & Reference \\
\hline MUP-uPA transgenic mice & $\begin{array}{c}\text { HCC progenitor cells showed autocrine IL-6 signaling that } \\
\text { stimulates in vivo growth and malignant progression }\end{array}$ \\
\hline $\begin{array}{c}\text { C.B-17 wild-type mice with an } \\
\text { intact immunity, C.B-17 SCID mice } \\
\text { with an impaired adaptive } \\
\text { immune response, C.B-17 }\end{array}$ & $\begin{array}{c}\text { Impaired immune-mediated clearance of pre-malignant senescent } \\
\text { hepatocytes secreting chemo- and cytokines resulted in the } \\
\text { development of murine HCCs }\end{array}$ \\
$\begin{array}{c}\text { SCID/beige mice with defects in } \\
\text { NK-cell and macrophage function }\end{array}$ & & \\
\hline
\end{tabular}


Table 1. Cont

\begin{tabular}{|c|c|c|}
\hline Animal Model & Results & Reference \\
\hline $\begin{array}{l}\text { Rat model of choline-deficient, } \\
\text { L-amino acid-defined diet } \\
\text { (CDAA)-Male Sprague-Dawley } \\
\text { rats Nude mice }\end{array}$ & $\begin{array}{l}\text { Aspirin or nimesulide administration decreased the number of } \\
\text { preneoplastic and neoplastic nodules Celecoxib treatment was } \\
\text { highly effective in inhibiting the multiplicity and size of liver } \\
\text { preneoplastic lesions COX (cyclooxygenase)-2 inhibitors (celecoxib } \\
\text { and meloxicam) enhanced tumor cell apoptosis and reduced } \\
\text { proliferation }\end{array}$ & [57] \\
\hline IL-6-/-/TLR-4-/- C57BL/6J mice & $\begin{array}{l}\text { Hepatic stem/progenitor marker CD133 was responsible for driving } \\
\text { and maintaining HCC. CD133 expression can be induced by IL-6 } \\
\text { and hypoxic conditions in a STAT3-dependent manner }\end{array}$ & [59] \\
\hline $\begin{array}{l}\text { RAW264.7-shNC/shAIF1 cells and } \\
\text { Hepa1-6 cells injected in C57BL/6 } \\
\text { mice }\end{array}$ & $\begin{array}{l}\text { Mouse cytokine antibody array analysis showed that macrophages } \\
\text { overexpressing AIF1 (Allograft Inflammatory Factor 1) secreted } \\
\text { high levels of CXCL16, which is reported to facilitate the migration } \\
\text { and invasion of HCC }\end{array}$ & [60] \\
\hline C57/BL6 mice & $\begin{array}{c}\text { The gut microbiota-driven COX-2 pathway produced PG } \\
\text { (Prostaglandin)-E2 which plays a pivotal role in suppressing } \\
\text { antitumor immunity and promoting HCC onset }\end{array}$ & [61] \\
\hline C57BL/6 mice & $\begin{array}{l}\text { Obesity induced alterations of gut microbiota increasing the levels } \\
\text { of DCA (deoxycholic acid); the enterohepatic circulation of DCA } \\
\text { provoked senescence-associated secretory phenotype in hepatic } \\
\text { stellate cells, which in turn secreted inflammatory and } \\
\text { tumour-promoting factors in the liver facilitating HCC development }\end{array}$ & [62] \\
\hline C57BL/6 mice & $\begin{array}{l}\text { Pro-inflammatory conditions enhanced the migration of PGE2 } \\
\text { carried by nanoparticles from the intestine to the liver, where they } \\
\text { induced the inactivation of natural killer T cells (cancer cells escape } \\
\text { from immune control) }\end{array}$ & [63] \\
\hline Tak1 $\Delta$ Hep mice & $\begin{array}{l}\text { TGF- } \beta \text { promoted HCC development by inducing hepatocyte } \\
\text { apoptosis and compensatory proliferation in early phases of } \\
\text { tumorigenesis, and inducing expression of anti-apoptotic, } \\
\text { pro-oncogenic and angiogenic factors during tumor progression. }\end{array}$ & [64] \\
\hline BALB/c mice & $\begin{array}{l}\text { Tim-3 (immune regulator, involved in many inflammation-related } \\
\text { diseases) expression in tumor-associated macrophages promoted } \\
\text { HCC growth }\end{array}$ & [65] \\
\hline
\end{tabular}

\subsection{Inflammation and Tissue Remodeling}

Chronic inflammation also leads to tissue remodeling through the crosstalk among several cell types in the liver microenvironment. Stromal cells, including fibroblasts and HSCs, can enhance ECM (extra cellular matrix) synthesis [66]. The immune cells can contribute to ECM remodeling through the activation of stromal cells or the synthesis of MMPs (matrix metallo peptidases) that specifically cleave ECM modifying the structure and function of the HCC microenvironment. With positive feed-back loop, the activated HSCs, but also Kupffer cells, macrophages and platelets are responsible for the secretion of TGF- $\beta$ that in turn activates more HSCs. As a result, the production and the release of ECM molecules, tissue MMPs, such as MMP2, 9, and 13, and MMPs inhibitors, such as TIMP1, are increased [67-69]. Tumor cells can induce remodeling by stromal cells through altered signaling pathways. ECM degradation allows tumor growth as well as facilitates the release of GFs and may also generate bioactive cleavage products or cell surface receptors, all of which represent pro-proliferative signals for tumor cells. Moreover, ECM degradation disables the growth-suppressing adhesion complexes favoring tumor cell evasion of growth suppression [70]. The remodeling that occurs at the ECM level is closely related to alterations in blood flow and the consequent hypoxia, and all of these processes ultimately favor tumor progression. In general, the cellular response to hypoxia consists of an increased expression of pro-angiogenic factors in tumor and non-tumor tissues. In particular there is an upregulation of VEGF which exerts its action at the level of hematopoietic stem cells and liver endothelial cells, which respond by forming new vessels that compensate for the lack of oxygen and nutrients necessary for tumor growth $[71,72]$. The resulted neo-angiogenesis is insufficient to compensate for 
the tumor hypoxia, consequently the remaining hypoxic areas in turn allow the formation of new vessels and the amplification of the angiogenic process [73,74]. These areas of hypoxia can also lead to molecular changes in signaling in non-tumor cells that modulate the HCC progression [75]. Moreover, it is known that regions of hypoxia are sites of accumulation for macrophages that in this condition assume a phenotype associated with increased expression of tolerogenic molecules, such as PD-L1 and IL-10, as well as pro-angiogenic factors, such as angiopoietin 1, VEGF, and MMP-9 [76]. One of the key signals that are activated by hypoxia is represented by HIFs (hypoxia-induced factors) which in turn activate the transcription of genes involved in EMT (epithelial-mesenchymal transition), invasion of the extracellular matrix and in other processes leading to tumor spread. Other findings revealed the existence of HIF-independent regulation of tumor angiogenesis and chemo-resistance under hypoxic conditions [77]. Furthermore, several studies explored the role of signaling pathways such as YAP (yes associated-protein), MMPs, HMGB1 (high mobility group box 1) and glucose metabolism enzymes in mediating the effects triggered by hypoxia in HCC [59] (Table 1). Guise C.P. and colleagues also described the hypoxia-activated bio-reductive pro-drugs, which would be activated by enzymatic reduction under hypoxic conditions [78]. An attractive possibility consists in targeting key molecules specifically induced in hypoxic cells, such as the HIF inhibitors (HIF1 $\alpha$ mRNA antagonist RO7070179) or molecules that specifically target the hypoxic fractions of tumors such as HAPs (hypoxia-activated prodrugs). These drugs are being administrated in combination with Sorafenib in ongoing phase I/II trials (clinicaltrials.gov Identifier: NCT02564614, NCT01497444 and NCT00862082). In addition, strategies such as oxygen supplement [79] and vessel normalization [80] could represent an effective option in the treatment of hypoxic cancers.

\subsection{Inflammation and the Immune Response in HCC}

From the interaction between the immune system, tumor cells and microenvironment derive a specific relationship between pro-tumor and anti-tumor factors, which changes over time and can either result in tumor elimination or elicit tumor progression. All tumors could indeed be considered potentially immunogenic and the host immune system is able to generate $\mathrm{T}$ cell responses that recognize and eradicate cancer cells. Several immune check point factors, including CTLA-4 (cytotoxic t-lymphocyte antigen-4) and programmed cell PD-1 (programmed death-1), downregulate the amplitude of immune response participating in peripheral self-tolerance. Cancer can use these signaling pathways leading to overexpression of check point molecules. One of the major effects of this upregulation is the inhibition of $\mathrm{T}$ cell activity (CD8+ effectors and CD4+ helpers which integrate adaptive and innate effector mechanisms) and the ensuing suppression of tumor immunity as a major mechanism of immune resistance. Moreover, the continuous interaction among tumor cells, immune cells and TME (tumor microenvironment), significantly contributes to these resistance mechanisms [81]. It is widely accepted that the TME of HCC is strongly immunosuppressive, thus resulting in immune tolerance and evasion by different mechanisms. A comprehensive integrated analysis of HCC conducted by the Cancer Genome Atlas Research Network revealed that approximately $25 \%$ of HCC cases present high inflammatory scores, with high or moderate levels of lymphocyte infiltration [82]. Although the high density of TILs (Tumor-Infiltrating Lymphocytes) is normally associated with a response of the host immune system against cancer and better outcome [83], this cellular response can be dysfunctional with a higher proportion of CD4+ (helper or T regulatory cells) to CD8+ cells. Major suggestions also indicate that HCC tumor cells may directly modify the liver microenvironment by recruiting Treg (regulatory T-cells) [84,85]. This scenario induces immune tolerance and could be associated to worse prognosis [86]. Moreover, TILs can be also found in the premalignant status of cirrhosis, but they were shown to be insufficient to suppress tumor progression [87]. The cytotoxic activity of CD8+ $\mathrm{T}$ cells are impaired though several mechanisms involving tumor cells, inflammatory cells and stromal cells. TAFs (Tumor-Associated Fibroblast), including HSCs, can promote the differentiation of peripheral blood monocyte into MDSC (myeloid derived suppressor cells) through IL-6/STAT3 signaling [88]. Both TGF- $\beta$ and cytokines (such as IL-10), 
secreted by HSCs, Kupffer cells, TAMs (tumor associated macrophages), and platelets, determine an expansion of MDSCs which in turn play a key role in enabling the effector T cells, enhancing the immune check-point signaling and decreasing NK (natural killer) cell cytotoxicity and cytokine production $[89,90]$. The presence of these immunosuppressive cells correlates with reduced TILs, elevated tumorigenicity, aggressive phenotype in HCC patients [91]. Moreover, MDSCs can contribute to the creation of an immunosuppressive TME, by inducing activation of Treg cells and inhibiting the secretion of IFN- $\gamma$ (Interferon gamma) by NK cells [92]. MDSCs also compete with T cells for energy resources (e.g., arginine and cysteine) [93]. The binding of the ligand galectin-9 on MDSCs with the receptor TIM-3 (T cell immunoglobulin and mucin domain-containing protein 3 ) on T cells determine their apoptosis [94]. Furthermore, in advanced HCC it has been hypothesized that MDSCs may interact with Kupffer cells to enhance PD-L1 expression, thus inhibiting cytotoxicity and cytokine release by NK cells [95]. Similarly to TILs, also for other immune cells, such as TAMs and tumor-associated neutrophils (TANs), recognition of pro-tumor and anti-tumor subtypes has been shown in several studies [96-98]. HCC cells play a key role in inducing the differentiation of circulating monocytes in M2 pro-tumor macrophages through the secretion of specific cytokines and growth factors, such as IL-4, IL-13, CSF-1 (Colony Stimulating Factor-1), CTGF (Connective Tissue Growth Factor) [60,99] (Table 1). Moreover, Osteopontin, secreted by HCC cells, induces both PD-L1 expression and attraction of M2 in the tumor site [100]. TAMs together with MDSCs, through the down regulation of immune-permissive IL-6 and IL-12 and over-expression of immune-suppressive IL-10, reduce both innate and adaptive immunity by impairing CD8 + T cells and NK cells respectively [101]. Similarly to TAMs, pro-tumoral N2 TANs are activated by IFNs and TGF- $\beta$, and induce apoptosis of CD8+ T cells via TNF alpha-mediated nitric oxide production [102,103]. Recently, TANs regulatory $\mathrm{T}$ cells are been associated to HCC Sorafenib-resistance and progression [104]. Recently, Liao et al. also suggested a cooperation of PD-1 and other immune checkpoint pathways that allows the escape of cancer cells from the control operated by the immune system [31]. This tolerant immune microenvironment is also attributed to an imbalance between pro-inflammatory and anti-inflammatory cytokines in HCC, closely correlating with increased PD-L expression. Thus, the development of ICI (immune checkpoint inhibitors) able to induce the immune system to attack cancer cells has a key role in the development of new therapeutic strategies against cancer. The expression of PD-L1 at the level of tumor cells is considered the main factor for the identification of the patients who may benefit from PD-1 axis targeted therapy. However, a significant percentage of patients with this positivity do not respond to these therapies, suggesting the existence of other interactions that are independent of PD-L1. Interesting results revealed that the immune-responsive signature is related to early stage HCC and could be associated with favorable prognosis and response to ICIs therapies [105]. This idea was supported by other studies that showed an initial prevalence to immune response against tumor antigens followed by dysfunctional effector cells in later stages of HCC [106]. Thanks to new technologies, efforts are being made to correlate the probability of transition from an inflammatory state to a tumor with a given immune arrangement in the liver. Integrated data derived from transcriptomic signature and immunohistochemistry open new perspectives for stratification of patients who might benefit for long-term from immune checkpoint therapy or other therapeutic approaches overcoming the immunosuppressive and dysfunctional HCC immune system [107].

\subsection{Other Microenvironmental Factors Involved in Hepatocarcinogenesis}

New areas of research indicate other aspects of the microenvironment, such as diet, gut microflora and micro-vesicles derived from cell subpopulations within the liver, in HCC carcinogenesis and progression [108-111]. Although it is currently difficult to define the exact causal mechanisms, these aspects warrant further investigation in greater detail in coming years. High fat diet-related microbial products, deriving from the gut, actively modulate a senescence-associated secretory phenotype on HSCs, with the ensuing production of PGE2 (prostaglandin E2) and inhibition of NK 
and cytotoxic T cells. Cytotoxicity may also be reduced by the effects of Gram-positive bacteria on the bile acid metabolism thus decreasing CXCL16 expression by LSECs [61-63,112].

\subsection{HCC Etiology and Chronic Inflammation}

The $80 \%-90 \%$ HCC of cases occur in the setting of chronic inflammation due to various etiological agents, such as toxins, viruses, excessive alcohol consumption and NAFLD/NASH. In these contests the cancer can represent the evolution of a fibrotic process in the presence or absence of cirrhosis (Figure 3).

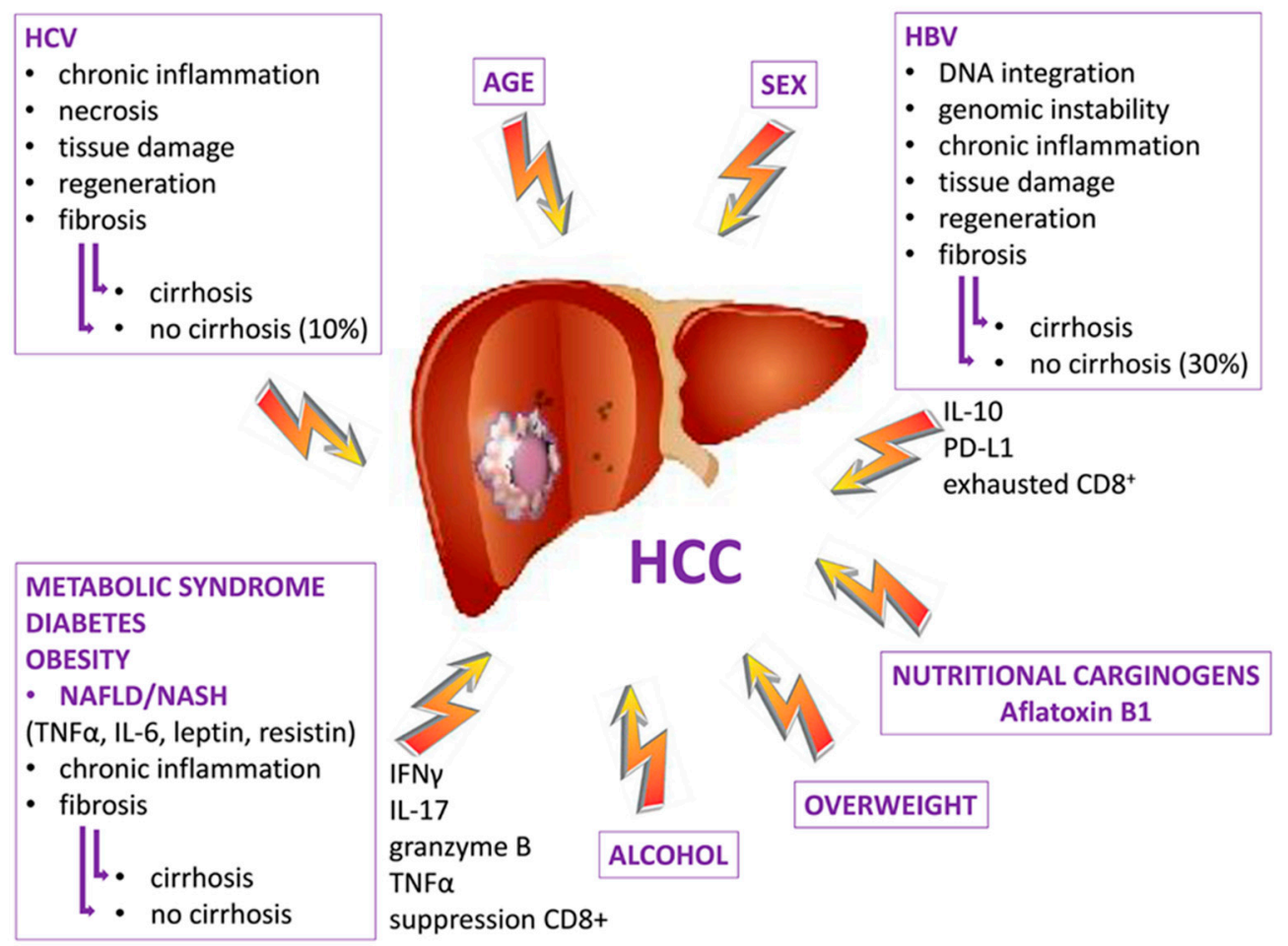

Figure 3. Cooperating risk factors for HCC onset. Factors with a viral and non-viral etiology may be responsible for the onset of the HCC by releasing specific mediators that lead to the formation of an inflammatory microenvironment that predisposes to the formation of fibrosis which can develop into cirrhosis which in some cases is not an essential condition for the development of HCC.

However, it will be considered also HCC "de novo" occurring in a little percentage of patients $(10 \%-20 \%)$ without concomitant fibrosis/cirrhosis and therefore without chronic inflammation [113]. Considering most inflamed-HCC, the progression of the fibrotic process is associated with an altered hepatic structure and an even greater alteration of immunological proteins important for the control of inflammation of the healthy liver, such as the C3 and C4 proteins, that appear strongly down regulated in the cirrhotic liver [114,115]. As a general rule, increasing inflammation is associated with a microenvironment with enhanced immunosuppressive signature. The chemokine networks CXCR3/CXCL10 and CCR6/CCL20 [116,117] together with TGF $\beta$ [64] (Table 1) play a key role in orchestrating the recruitment of Treg and macrophages polarized in their immunosuppressive phenotype M2 [65] (Table 1). Kupffer cells produce also enhanced levels of PD-L1 expression [118]. The absence of cirrhosis is found primary in 30\% of HCC derived from HBV infection and in variable percentage of HCC derived from NAFD/NASH, but also in about $10 \%$ of HCV infection. In chronic HBV infection, high viral load, mutation BCP T1762/A1764 or overweight are considered risk factors for the occurrence of HCC even in the absence of cirrhosis $[119,120]$. In chronic HCV infection, cell death is largely due to inflammation and necrosis resulting in tissue damage, regeneration and fibrosis. The absence of cirrhosis in the HCV-related tumors is found after virus eradication treatment and in the presence of other risk factors that are in any case responsible for the inflammatory state [121,122]. 
Growing evidences revealed higher levels of IL6, TNF $\alpha$, IL1 $\beta$, and IL10 in HCC patients with cirrhosis compared with those infected with HBV or HCV in the absence of cirrhosis [123-125].

Although innate and adaptive immune responses restrict HBV replication, chronic viral infection promote inflammation together with a program that support HCC progression through immunosuppressive TME, consisting in IL-10, PD-L1 expression and exhausted CD8+ T cell [126]. Hwang IC and colleagues proposed the existence of different pathways of carcinogenesis triggered by viral infections respect to those induced by other agents [127]. They conducted a population-based cohort study on 2,336 HCC Korean patients in which the risk of HCC occurrence was related to the aspirin assumption. Aspirin inhibits COX, thus affecting platelet action that, as previously mentioned, plays a pivotal role in inducing the immune-mediated liver inflammation. The results revealed a protective role exerted by aspirin in patients with HBV infection without cirrhosis, in which platelets may promote the inflammation immune-mediated triggered by chronic viral infection [38]. In this contest, the risk of HCC was significantly lowered by aspirin. If further studies confirm these results, aspirin could be used to lower the risk of HCC in a selected patient population.

Moreover, a well-known link was established between inflammation and epigenetic mechanisms and the comparison of methylation profiles between patients with HBV infection, HCV infection and alcohol consumption has revealed a specific set of hypermethylated CpG islands for each group [128]. Recent integrated studies highlighted other interesting correlation between immune landscape, including PD-L1/PD-1 expression, and HCC etiopathology. In this regard, the results based on the analysis of 956 patients showed a closer relationship between inflammatory phenotype, PD-L1 overexpression and HCV infection compared to that observed in case of HCC deriving from HBV or excessive alcohol consumption [129]. Further efforts will be needed to extend these analyzes to include HCC cases resulting from NAFLD/NASH. With the decrease in HCC cases due to virus eradication treatments, excessive alcohol consumption and NAFLD/NASH represent the main persistent risk factors of HCC in the Western world. The presence of NAFLD, which is associated with type 2 diabetes and obesity, causes the release of numerous inflammatory factors, such as TNF-alpha, IL-6, leptin, and resistin, that are at the base of the steatosis process and that promote tumorigenesis [130]. In a recent study, aimed to elucidate the molecular mechanisms involved in the development of NASH, a transcriptional and immune profiling of NASH patients before and after LSI (lifestyle intervention) was performed [131]. The results revealed a hepatic gene signature associated with NASH regression due to LSI independently of body weight loss. The genes specifically associated with NASH included loci linked to inflammatory responses, antigen presentation and cytotoxic cells. Furthermore, analysis in an independent cohort showed a close link between NASH and alterations in blood immune cell types, including cDC (dendritic cells) type 1 and 2, and cytotoxic CD8+ T cells. The hepatic expression levels of some of these immune-related genes, such as CXCL9 and CXCL10, and lysozyme, were significantly higher in NASH respect to NAFLD patients. Blood cytotoxic CD8+ T cells expressing perforin showed associations with hepatic genes related to cytotoxic and IFN $\gamma$ responses (GZMA, CD226, IRF1), T helper differentiation (ITK), and TNF $\alpha$ signaling (TNFAIP2). Interestingly, these results found that disease activity, lobular inflammation and ballooning in NASH is related to the accumulation of CD8+ T lymphocytes in the liver. Hepatic CD8+ T cells are also linked to an enhanced expression of genes from the signature of active NASH. In NAFLD/NASH-related HCC tumors were found increased levels of IgA-producing cells that induce tumorigenesis though PD-L1 and IL-10 expression and the suppression of CD8+ T cells [132]. Generally, in non-viral HCC patients were found higher levels of IFN $\gamma$, IL-17, Granzyme B, and TNF $\alpha$ with respect to those revealed in HBV-related patients, thus explaining the more immunosuppressive environment created by viral infection [126].

\section{Preclinical Studies in HCC Immunotherapy}

Due to the lower response rate to ICB (immune-checkpoint blockade)-based immunotherapies in preclinical studies, ICB agents were also tested in combination with other systemic treatments. Chen $\mathrm{Y}$ and collaborators showed that the prevention of an immunosuppressive microenvironment, 
through CXCR4 inhibition, facilitated the response to anti PD-1 therapy in HCC mouse models previously treated with Sorafenib [133]. Most recently, using both subcutaneous and hepatic orthotopic models, Brown et al. provided evidence that inhibiting IDO in combination with ICIs could add therapeutic benefit in tumors overexpressing IDO [134]. Considering that angiogenesis inhibitors and ICIs are used for anticancer therapies against advanced HCC, Kimura T and colleagues also reported that VEGFR inhibitor Levantinib enhanced the antitumor activity of PD-1 blockade, decreasing the proportion of the monocyte and macrophage population and increasing CD8+ T cell populations in the Hepa1-6 mouse HCC syngeneic model [135].

The activity of immunotherapeutic agents may also be improved by epigenetic drugs that have immune-mediated antitumor effects. This hypothesis was studied by Llopiz D et al., who investigated the therapeutic efficacy of anti-CTLA-4 and anti-PD-1 antibodies in combination with the HDAC (histone deacetylase inhibitor) inhibitor Belinostat in a subcutaneous Hepa129 HCC model. This drug combination resulted in an improvement of the antitumor activity of anti-CTLA-4 but not of anti-PD-1 therapy [136]. Moreover, preclinical data suggested that polyIC (polyinosinic-polycytidylic acid) represents an efficient prevention strategy against liver tumorigenesis and a powerful combination immunotherapy for HCC activating NK cells, macrophages and some T-cell subpopulation [137]. The expansion of TAMs in the TME allows the immune escape of cancer cells. Therefore, strategies aimed to prevent TAM trafficking enhanced the efficacy of ICI in HCC mouse models [101]. Other strategies targeting immunosuppressive cells have been tested in the preclinical setting. The FDA-approved MDSCs inhibitor Tadalafil may enhance the Cytokine-induced killer (CIK) cell-based immunotherapy in HCC patients [138].

Murine HCC models have also been used to investigate the ability of vaccines to trigger a specific response by $\mathrm{T}$ cells and to assess the efficacy of CAR-T (chimeric antigen receptor T) cells. Recently, Liu Z et al. investigated the effects of the fusion of the potent immune-adjuvant HMGN1 (high-mobility group nucleosome binding protein 1) to AFP in a AFP-expressing lentiviral vector (lenti-HA). This vehicle was extensively employed for genetic immunization with high transduction efficacy and a good safety profile. The antitumor immunity of Lenti-HA was assessed in ectopic, orthotopic, and autochthonous HCC models, demonstrating that HMGN1 increased the antitumor immunity of AFP-expressing lentiviral vaccines in HCC mice and human cells, and thus providing a new therapeutic strategy for HCC [139]. Moreover, several findings demonstrated that CAR T-cell immunotherapy targeting intracellular/secreted tumor antigens can elicit a potent antitumor response. The effects of CAR-T cells targeting AFP (alpha-fetoprotein) or GPC3 (glypican-3) were also evaluated with promising results in HCC patients $[140,141]$.

\section{Clinical Studies in HCC Immunotherapy}

The inhibitors of immune check points are currently investigated in clinical trials alone or in association with local regional interventions or standard therapies involving chemotherapy or molecularly targeted drugs. Tremelimumab, a monoclonal antibody against CTLA-4, was the first ICB drug tested in HCC patients. NCT01008358 clinical trial showed that this drug had a satisfactory safety profile and produced $17.6 \%$ partial response in evaluable patients.

Considering the PD-1 inhibitors, Nivolumab was administrated to patients with advanced HCC and poor survival prospects in a phase I/II trial (NCT01658878). The ORR (objective response rate) of $15-24 \%$ and promising survival durations led to the approval by the U.S. FDA. Pembrolizumab, also received FDA approval following the results obtained from NCT02702414 phase II study that reported one complete response and 16 partial responses among 104 patients and found drug effectiveness and tolerability. Pembrolizumab has also been evaluated in two other randomised, phase III trials as a second-line HCC treatment (NCT02702401 and NCT03062358). However, data from NCT02702401 study revealed that co-primary endpoints of OS (overall survival) and PFS (progression-free survival) were not achieved in advanced HCC (Table 2). 
Table 2. Major trials in HCC involving anti-PD-1/PD-L1 agents-based immunotherapies.

\begin{tabular}{|c|c|c|c|c|}
\hline Name & Phase & Line of Treatment & Strategy & Primary Endpoint \\
\hline NCT03841201 & 2 & I & $\begin{array}{c}\text { Nivolumab (anti-PD-1/PD-L1) + Lenvatinib } \\
\text { (VEGFRs inhibitor) }\end{array}$ & $\begin{array}{l}\text { ORR (Objective response rate) } \\
\text { Safety and tolerability }\end{array}$ \\
\hline NCT03630640 & 2 & neo + adj & Nivolumab & RFS (Recurrence Free Survival) \\
\hline NCT02576509 & 3 & I & Nivolumab vs. Sorafenib (Raf inhibotor) & OS (Overall Survival) \\
\hline NCT03203304 & 1 & II & $\begin{array}{c}\text { Nivolumab Ipilimumab (anti CTLA-4) } \\
\text { Nivolumab }\end{array}$ & AEs (Adverse Events) \\
\hline NCT01658878 & $1 / 2$ & I & $\begin{array}{c}\text { Sorafenib } \\
\text { Nivolumab + Ipilimumab } \\
\text { Nivolumab + Cabozantinib } \\
\text { (RTK inhibitor) Nivolumab + Ipilimumab + } \\
\text { Cabozantinib }\end{array}$ & AEsORR \\
\hline NCT03510871 & 2 & neo & $\begin{array}{c}\text { Nivolumab + Ipilimumab } \\
\text { FT500 (NK cell product) +/- Nivolumab, }\end{array}$ & Tumor shrinkage \\
\hline NCT03841110 & 1 & II & $\begin{array}{c}\text { Pembrolizumab (anti-PD-1/PD-L1), } \\
\text { Atezolizumab (anti PD-L1), } \\
\text { Cyclophosphamide, Fludarabine }\end{array}$ & DLT (Dose Limiting Toxicities) \\
\hline NCT03682276 & $1 / 2$ & I & $\begin{array}{c}\text { Ipilimumab + Nivolumab } \\
\text { ALT-803 (IL-15 superagonist) }+ \\
\text { Pembrolizumab }\end{array}$ & Delay to surgery AEs \\
\hline NCT03228667 & 2 & II & $\begin{array}{c}\text { ALT-803 + Nivolumab } \\
\text { ALT-803 + Atezolizumab } \\
\text { ALT-803 + Avelumab (anti PD-L1) }\end{array}$ & ORR \\
\hline NCT04134559 & 2 & II & Pembrolizumab & $\begin{array}{l}\text { irBOR (immune-related Best } \\
\text { Overall Response) }\end{array}$ \\
\hline NCT02595866 & 1 & II & Pembrolizumab & $\begin{array}{c}\text { AEs } \\
\text { ECIs (Events of Clinical Interest) }\end{array}$ \\
\hline NCT03337841 & 2 & neo + adj & Pembrolizumab & One-year RFS \\
\hline NCT04099277 & 1 & II & $\begin{array}{c}\text { LY343515 } \\
\text { 1+/- Pembrolizumab }\end{array}$ & DLT \\
\hline NCT03222076 & 2 & neo & $\begin{array}{l}\text { Nivolumab } \\
+ \text { /- Ipilimumab }\end{array}$ & AEs \\
\hline NCT03383458 & 3 & adj & Nivolumab & RFS \\
\hline NCT03655002 & 1 & II & $\begin{array}{l}\text { Nivolumab, Cyclophosphamide, IRX-2 } \\
\text { (cytokine-based biologic agent) }\end{array}$ & Safety \\
\hline NCT03812562 & 1 & I & $\begin{array}{c}\text { Yttrium Y } 90 \text { glass microspheres, } \\
\text { Nivolumab }\end{array}$ & RR (Recurrence Rate) \\
\hline NCT03867084 & 3 & adj & Pembrolizumab & $\begin{array}{c}\text { RFS } \\
\text { OS }\end{array}$ \\
\hline NCT03755739 & $2 / 3$ & I & Pembrolizumab & OS \\
\hline NCT02702401 & 3 & II & Pembrolizumab & $\begin{array}{l}\text { PFS } \\
\text { OS }\end{array}$ \\
\hline NCT03062358 & 3 & II & Pembrolizumab & OS \\
\hline NCT02702414 & 2 & II & Pembrolizumab & ORR \\
\hline NCT03006926 & 1 & II & Pembrolizumab + Levantinib & $\begin{array}{l}\text { AEs } \\
\text { DLT }\end{array}$ \\
\hline NCT03713593 & 3 & I & $\begin{array}{c}\text { Levantinib }+/- \text { Pembrolizumab } \\
\text { Pembrolizumab }\end{array}$ & OS \\
\hline NCT02940496 & $1 / 2$ & II & $\begin{array}{c}\text { Pembrolizumab }+ \text { elbasvir/grazoprevir }+ \\
\text { ribavirin } \\
\text { (antiviral drugs) }\end{array}$ & DLT \\
\hline NCT03511222 & 2 & $\mathrm{I}$ & $\begin{array}{l}\text { Vorolanib (antiangiogenic agent) }+ \\
\text { Pembrolizumab }\end{array}$ & $\begin{array}{c}\text { RP2D (Recommended phase II } \\
\text { dose) }\end{array}$ \\
\hline NCT03299946 & 1 & neo & Cabozantinib + Nivolumab & $\begin{array}{c}\text { AEs } \\
\text { proceed to surgery }\end{array}$ \\
\hline NCT03412773 & 3 & $\mathrm{I}$ & Tislelizumab (anti PD-1/PD-L1) & $\begin{array}{l}\text { OS } \\
\text { ORR }\end{array}$ \\
\hline
\end{tabular}

The evaluation of PD-L1 expression levels is useful to predict the response to a therapeutic regimen based on ICB drugs. In phase III studies, Durvalumab (anti-PD-L1) monotherapy produced a major promising response rate in HCV-positive HCC patients expressing higher levels of PD-L1 [30,142] (Table 3). 
Table 3. Major trials in HCC involving anti-PD-L1 agents-based immunotherapies.

\begin{tabular}{|c|c|c|c|c|}
\hline Name & Phase & Line of Treatment & Strategy & Primary Endpoint \\
\hline NCT03638141 & 2 & II & $\begin{array}{l}\text { Durvalumab (anti PD-L1)+ } \\
\text { Tremelimumab (anti CTLA-4) }\end{array}$ & ORR (Objective Response Rate) \\
\hline NCT03298451 & 3 & I & Durvalumab +/- Tremelimumab & OS (Overall Survival) \\
\hline NCT03847428 & 3 & I & $\begin{array}{c}\text { Durvalumab + Bevacizumab } \\
\text { (anti-VEGFA) }\end{array}$ & RFS (Recurrence-Free Survival) \\
\hline NCT03434379 & 3 & I & $\begin{array}{c}\text { Atezolizumab (anti PD-L1) + } \\
\text { Bevacizumab }\end{array}$ & $\begin{array}{c}\text { PFS (Progression-Free Survival) } \\
\text { OS }\end{array}$ \\
\hline NCT02715531 & 1 & I & Atezolizumab + Bevacizumab & $\begin{array}{l}\text { AEs (Adverse Events) OR } \\
\text { (Objective Response) PFS }\end{array}$ \\
\hline NCT03755791 & 3 & I & $\begin{array}{c}\text { Cabozantinib (RTK inhibitor) + } \\
\text { Atezolizumab }\end{array}$ & $\begin{array}{l}\text { PFS } \\
\text { OS }\end{array}$ \\
\hline NCT03937830 & 2 & II & $\begin{array}{c}\text { Durvalumab + Bevacizumab + } \\
\text { Doxorubicin (TACE) }\end{array}$ & PFS \\
\hline NCT02519348 & 2 & II & $\begin{array}{l}\text { Durvalumab }+/- \text { Tremelimumab } \\
\text { Tremelimumab +/- Durvalumab } \\
\text { Durvalumab +/- Bevacizumab }\end{array}$ & $\begin{array}{c}\text { AEs } \\
\text { DLT (Dose Limiting Toxicity) }\end{array}$ \\
\hline
\end{tabular}

In addition, several ongoing studies are based on therapeutic regimens in which ICB drugs are administered in association with tyrosine kinase inhibitors, anti-VEGF antibodies and ablative interventions. NCT01658878 study (Table 2) showed that blocking simultaneously both PD-1/PD-L1 and CTLA- 4 with Nivolumab and Ipilimumab respectively, an average ORR of $31 \%$ and an acceptable safety profile were produced in Sorafenib-treated advanced HCC patients. Double blockade with Durvalumab and Tremelimumab was tested in NCT02519348 phase I/II trial with positive results, achieving an ORR of $25 \%$ with a manageable toxicity profile. A global phase III trial (NCT03298451) was activated to compare the efficacy of different regimens including Durvalumab as monotherapy, Durvalumab/Tremelimumab combination therapy and Sorafenib monotherapy as first-line treatment in HCC patients (Table 3).

Other combined therapies are being tested in current clinical trials and appear to be promising. Several studies evaluated the simultaneous administration of ICB therapy with targeted drugs such as Atezolizumab (anti-PD-L1) plus Bevacizumab (anti-VEGF) (NCT02715531) (Table 3), Pembrolizumab plus Lenvatinib (a multi-VEGFR inhibitor) (NCT03006926 and NCT03713593) (Table 2), and SHR-1210 (anti-PD-1) plus Apatinib (VEGFR2 inhibitor) (NCT04191889) (Table 4).

Table 4. Major trials in HCC involving anti-PD1 agents-based immunotherapies.

\begin{tabular}{|c|c|c|c|c|}
\hline Name & Phase & Line of Treatment & Strategy & Primary Endpoint \\
\hline NCT03864211 & $1 / 3$ & II & Toriplimab (anti-PD-1) & $\begin{array}{c}\text { AEs (Adverse Events) ORR (Overall } \\
\text { Response Rate) }\end{array}$ \\
\hline NCT03914352 & & & SHR-1210 (anti-PD-1) & $\begin{array}{c}\text { OS (Overall Survival) } \\
\text { DFS (Disease-Free Survival) }\end{array}$ \\
\hline NCT03605706 & 3 & I & $\begin{array}{c}\text { SHR-1210 + FOLFOX4 } \\
\text { FOLFOX4 } \\
\text { Sorafenib (Raf inhibitor) }\end{array}$ & 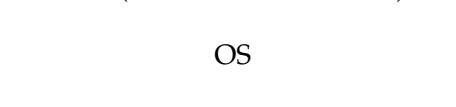 \\
\hline NCT04191889 & 2 & & $\begin{array}{c}\text { FOLFOX + Apatinib (VEGFR-2 } \\
\text { inhibitor) + Camrelizumab } \\
\text { (SHR-1210) }\end{array}$ & ORR \\
\hline NCT04152356 & & I & PD- $1+$ Sorafenib & DFS \\
\hline NCT04220944 & 1 & I & Sintilimab (anti-PD-1) & PFS (Progression Free Survival) \\
\hline NCT04174781 & 2 & & Sintilimab & PFS \\
\hline NCT04167293 & $2 / 3$ & I & Sintilimab & 24-week PFS \\
\hline NCT04229355 & 3 & I & $\begin{array}{l}\text { Lenvatinib (VEGFRs inhibotor)vs. } \\
\text { PD-1 inhibitor }\end{array}$ & PFS \\
\hline NCT03949231 & 3 & & Toripalimab & OS \\
\hline NCT03966209 & 1 & II & JS001 (PD-1 inhibitor) & $\begin{array}{l}\text { Adverse Events Rate } \\
\text { Graft Rejection Rate }\end{array}$ \\
\hline
\end{tabular}


Table 4. Cont.

\begin{tabular}{ccccc}
\hline Name & Phase & Line of Treatment & Strategy & Primary Endpoint \\
\hline NCT03655613 & $1 / 2$ & II & APL-501 (PD-1 inhibitor) + & DLT (Dose Limiting Toxicity) \\
NCT04172506 & $1 / 2$ & II & APL-101 (c-Met inhibitor) & ORR \\
NCT03680508 & 2 & I & TSR-022 (anti-TIM-3) + TSR-042 & OR (Objective Response) \\
& & & Pembrolizumab (anti-PD-1/PD-L1) & AEs \\
NCT03939975 & 2 & II & Nivolumab (anti-PD-1/PD-L1) & Response \\
NCT02988440 & 1 & & JS001 & AEs \\
NCT02795429 & 2 & II & PDR001 (anti-PD-1)+ Sorafenib & DLT \\
NCT034746280 (c-Met/HGFR & ORR \\
\hline
\end{tabular}

Moreover, the global phase III trial NCT03434379 (Table 3) has been recently launched to compare the survival outcome of Atezolizumab and Bevacizumab combination with that of Sorafenib monotherapy as first-line setting for advanced or metastatic HCC.

Enhanced and synergistic effects can also be hypothesized following treatments that provide immune-checkpoint inhibitors combined with locoregional intervention. A phase II trial of Nivolumab in association with mRFA (monopolar radiofrequency ablation) therapy (NCT03630640) proposed to test the safety and efficacy of treatment with Nivolumab in neoadjuvant and adjuvant setting in patients with advanced HCC treated by electroporation in curative intent. Similarly, NCT03337841 study is evaluating the efficacy of the immune checkpoint inhibitor Pembrolizumab in preventing the recurrence of HCC when administered before and after curative surgery or ablation (Table 2).

Furthermore, cell-based immunotherapies exploiting the ability of certain cellular components to reactivate the immune response and the major trials are listed in Table 5.

Table 5. Major trials in HCC involving cell-based immunotherapies.

\begin{tabular}{|c|c|c|c|}
\hline Name & Phase Line of Treatment & Strategy & Primary Endpoint \\
\hline NCT02723942 & $1 / 2$ & $\begin{array}{l}\text { CAR-T cell immunotherapy targeting } \\
\text { GPC3 }\end{array}$ & $\begin{array}{l}\text { Radiological assessment of } \\
\text { therapeutic effect }\end{array}$ \\
\hline NCT02905188 & $\mathrm{I} / \mathrm{II}$ & $\begin{array}{c}\text { GPC3-CAR (GLYCAR T cells) + } \\
\text { Cytoxan and Fludarabine } \\
\text { (lymphodepleting chemotherapy) }\end{array}$ & DLT (Dose Limiting Toxicity) \\
\hline NCT03130712 & $1 / 2$ & GPC3-CART cells & AEs (Adverse Events) \\
\hline NCT03198546 & 1 & GPC 3 and/or TGF $\beta$ CAR-T cells & DLT \\
\hline NCT03013712 & $1 / 2$ & EpCAM-CAR T cells & AEs \\
\hline NCT03575806 & II & $\begin{array}{l}\text { Autologous Tcm (central memory T } \\
\text { cells) } \\
\text { anti-MUC1 CAR-pNK cells (Chimeric }\end{array}$ & $\begin{array}{l}\text { DFS (Disease-free Survival) } \\
\text { Clinical Efficacy Safety }\end{array}$ \\
\hline NCT02839954 & $1 / 2$ & $\begin{array}{l}\text { Antigen Receptor NK cells with } \\
\text { specificity for MUC1) }\end{array}$ & AEs \\
\hline NCT04106167 & & Allogeneic Natural Killer (NK) cells & OS (Overall Survival) \\
\hline NCT01147380 & 1 & Liver NK cell inoculation & Side Effect \\
\hline NCT03093688 & $1 / 2$ & $\begin{array}{l}\text { iNKT (invariant Natural Killer T) cells } \\
+ \text { PD- } 1+\text { CD } 8^{+} \mathrm{T} \text { cells }\end{array}$ & $\begin{array}{c}\text { AEs } \\
\text { ORR (Overall Response Rate) }\end{array}$ \\
\hline NCT03319459 & II & $\begin{array}{c}\text { FATE-NK100 (donor-derived NK) +/- } \\
\text { Cetuximab (EGFR inhibitor)+/- } \\
\text { Trastuzumab (anti-HER2) }\end{array}$ & 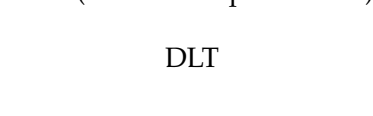 \\
\hline NCT02882659 & II & Dendritic Killer Cell (DKC) & $\begin{array}{l}\text { AEs } \\
\text { DLT } \\
\text { Safety }\end{array}$ \\
\hline
\end{tabular}


Table 5. Cont.

\begin{tabular}{|c|c|c|c|}
\hline Name & Phase Line of Treatment & Strategy & Primary Endpoint \\
\hline NCT02886897 & $1 / 2$ & $\begin{array}{l}\text { Autologous D-CIK (Dendritic and } \\
\text { Cytokine-Induced Killer) cells + } \\
\text { anti-PD-1 antibody }\end{array}$ & PFS (Progression Free Survival) \\
\hline NCT02632006 & $1 / 2$ & $\begin{array}{l}\text { Pluripotent Killer T Cells expressing } \\
\text { antibodies for PD-1 }\end{array}$ & OS \\
\hline NCT00562666 & 1 & $\begin{array}{c}\text { Autologous Gamma-delta T } \\
\text { Lymphocytes }\end{array}$ & AEs \\
\hline NCT03132792 & II & 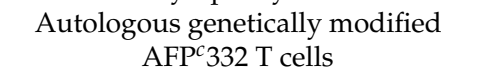 & $\begin{array}{l}\text { DLT } \\
\text { AEs }\end{array}$ \\
\hline NCT03592706 & $2 / 3$ & $\begin{array}{l}\text { Autologous IKC (Immune Killer } \\
\text { Cells) }\end{array}$ & $\begin{array}{c}\text { Change of tumor size } \\
\text { PFS } \\
\text { AEs }\end{array}$ \\
\hline NCT03998033 & $1 / 2$ & ET140202 Receptor (+) T cells & $\begin{array}{c}\text { RP2D (Recommended Phase } 2 \\
\text { Dose) }\end{array}$ \\
\hline NCT02678013 & 3 & Cytotoxic T Lymphocytes (CTL) & RFS (Recurrence Free Survival) \\
\hline NCT03836352 & II & $\begin{array}{c}\text { DPX-Survivac (T cell activating } \\
\text { therapy) + Pembrolizumab (anti } \\
\text { PD-1/PD-L1) +/- Cyclophosphamide }\end{array}$ & $\begin{array}{l}\text { ORR } \\
\text { AEs }\end{array}$ \\
\hline
\end{tabular}

Results from a phase I study evaluating GPC3 CAR-T cells in refractory or relapsed GPC3+ patients showed a slowdown in tumor progression (NCT02395250). Therefore, interesting clinical trials (NCT02905188 and NCT03198546) are now evaluating the safety and efficacy of T cells genetically engineered with a GPC3-CAR in patients with HCC. Interestingly, the possibility of infusing patients with anti-tumor immune cells such as NK and cytokine-induced killer cells, represents a new therapeutic approach studied in numerous clinical trials (NCT03093688, NCT03319459, NCT02886897).

Due to the ability to specifically infect and kill cancer cells, several onco-lytic viruses have been tested in clinical trials of patients with HCC (Table 6).

Table 6. Major trials in HCC involving oncolytic viruses-based immunotherapies.

\begin{tabular}{|c|c|c|c|c|}
\hline Name & Phase & $\begin{array}{l}\text { Line of } \\
\text { Treatment }\end{array}$ & Strategy & Primary Endpoint \\
\hline NCT03071094 & $1 / 2$ & & $\begin{array}{l}\text { Pexastimogene Devacirepvec (Pexa Vec is a } \\
\text { vaccinia virus based oncolytic } \\
\text { immunotherapy designed to stimulate the } \\
\text { immune system following infection and } \\
\text { replication within tumor cells) + } \\
\text { Nivolumab (anti PD-1/PD-L1) }\end{array}$ & $\begin{array}{c}\text { Safety DLT (Dose } \\
\text { Limiting Toxicity) } \\
\text { Anti-tumor activity Efficacy }\end{array}$ \\
\hline NCT02562755 & 3 & & Pexa-Vec + Sorafenib (Raf inhibitor) & OS (Overall Survival) \\
\hline
\end{tabular}

The recent NCT02562755 randomized phase III study determines whether treatment with vaccinia virus-based immunotherapy (Pexa-Vec) followed by Sorafenib increases survival compared to treatment with Sorafenib alone in patients with advanced HCC who have not received prior systemic therapy.

\section{Conclusions}

We reviewed multiple aspects of the role of the liver microenvironment and the genetic alterations in hepatocytes cells in relation to HCC development. A multitude of cross talking factors in the liver microenvironment modulate the progression of HCC and their full characterization is crucial to identify new therapies effective in the treatment of the tumor itself and the liver microenvironment, which reciprocally influence each other, to avoid the recurrence and resistance phenomena associated with current HCC therapies. As a result, many microenvironment inflammatory factors have been identified and are potential therapeutic targets. Many immunomodulatory drugs are currently in HCC clinical trials, either alone or in combination with other HCC therapies. 
We conclude that the inflammatory response is an active process that not only responds to carcinogenic events, but actively participates in them and is a promising target in its own right for new therapies.

Funding: This research was funded by ITALIAN MINISTRY OF PUBLIC HEALTH, grant number 6/2016.

Conflicts of Interest: The authors declare no conflict of interest.

\section{References}

1. Woo, H.G.; Park, E.S.; Thorgeirsson, S.S.; Kim, Y.J. Exploring genomic profiles of hepatocellular carcinoma. Mol. Carcinog. 2011, 50, 235-243. [CrossRef] [PubMed]

2. Multhoff, G.; Molls, M.; Radons, J. Chronic inflammation in cancer development. Front. Immunol. 2012, 2, 98. [CrossRef] [PubMed]

3. Grivennikov, S.I.; Greten, F.R.; Karin, M. Immunity, inflammation, and cancer. Cell 2010, 140, 883-899. [CrossRef] [PubMed]

4. Greten, T.F.; Wang, X.W.; Korangy, F. Current concepts of immune based treatments for patients with HCC: From basic science to novel treatment approaches. Gut 2015, 64, 842-848. [CrossRef] [PubMed]

5. Tu, T.; Budzinska, M.A.; Maczurek, A.E.; Cheng, R.; Di Bartolomeo, A.; Warner, F.J; McCaughan, G.W.; McLennan, S.V.; Shackel, N.A. Novel aspects of the liver microenvironment in hepatocellular carcinoma pathogenesis and development. Int. J. Mol. Sci. 2014, 15, 9422-9458. [CrossRef]

6. Zucman-Rossi, J.; Villanueva, A.; Nault, J.C.; Llovet, J.M. The genetic landscape and biomarkers of hepatocellular carcinoma. Gastroenterology 2015, 149, 1226-1239. [CrossRef]

7. de La Coste, A.; Romagnolo, B.; Billuart, P.; Renard, C.A.; Buendia, M.A.; Soubrane, O.; Fabre, M.; Chelly, J.; Beldjord, C.; Kahn, A.; et al. Somatic mutations of the beta-catenin gene are frequent in mouse and human hepatocellular carcinomas. Proc. Natl. Acad. Sci. USA 1998, 95, 8847-8851. [CrossRef]

8. Fujimoto, A.; Totoki, Y.; Abe, T.; Boroevich, K.A.; Hosoda, F.; Nguyen, H.H.; Aoki, M.; Hosono, N.; Kubo, M.; Miya, F.; et al. Whole-genome sequencing of liver cancers identifies etiological influences on mutation patterns and recurrent mutations in chromatin regulators. Nat. Genet. 2012, 44, 760-764. [CrossRef]

9. Huang, J.; Deng, Q.; Wang, Q.; Li, K.Y.; Dai, J.H.; Li, N.; Zhu, Z.D.; Zhou, B.; Liu, X.Y.; Liu, R.F.; et al. Exome sequencing of hepatitis B virus-associated hepatocellular carcinoma. Nat. Genet. 2012, 44, 1117-1121. [CrossRef]

10. Woo, H.G.; Wang, X.W.; Budhu, A.; Kim, Y.H.; Kwon, S.M.; Tang, Z.Y.; Sun, Z.; Harris, C.C.; Thorgeirsson, S.S. Association of TP53 mutations with stem cell-like gene expression and survival of patients with hepatocellular carcinoma. Gastroenterology 2011, 140, 1063-1070. [CrossRef]

11. Bressac, B.; Kew, M.; Wands, J.; Ozturk, M. Selective G to T mutations of p53 gene in hepatocellular carcinoma from southern Africa. Nature 1991, 350, 429-431. [CrossRef] [PubMed]

12. Sung, W.K.; Zheng, H.; Li, S.; Chen, R.; Liu, X.; Li, Y.; Lee, N.P.; Lee, W.H.; Ariyaratne, P.N.; Tennakoon, C.; et al. Genome-wide survey of recurrent HBV integration in hepatocellular carcinoma. Nat. Genet. 2012, 44, 765-769. [CrossRef] [PubMed]

13. Brechot, C. Pathogenesis of hepatitis B virus-related hepatocellular carcinoma: Old and new paradigms. Gastroenterology 2004, 127, S56-S61. [CrossRef] [PubMed]

14. Li, X.; Zhang, J.; Yang, Z.; Kang, J.; Jiang, S.; Zhang, T.; Chen, T.; Li, M.; Lv, Q.; Chen, X.; et al. The function of targeted host genes determines the oncogenicity of $\mathrm{HBV}$ integration in hepatocellular carcinoma. J. Hepatol. 2014, 60, 975-984. [CrossRef]

15. Paterlini-Brechot, P.; Saigo, K.; Murakami, Y.; Chami, M.; Gozuacik, D.; Mugnier, C.; Lagorce, D.; Bréchot, C. Hepatitis B virus-related insertional mutagenesis occurs frequently in human liver cancers and recurrently targets human telomerase gene. Oncogene 2003, 22, 3911-3916. [CrossRef]

16. Hino, O.; Tabata, S.; Hotta, Y. Evidence for increased in vitro recombination with insertion of human hepatitis B virus DNA. Proc. Natl. Acad. Sci. USA 1991, 88, 9248-9252. [CrossRef]

17. Nault, J.C. Pathogenesis of hepatocellular carcinoma according to aetiology. Best Pract. Res. Clin. Gastroenterol. 2014, 28, 937-947. [CrossRef]

18. Bartosch, B.; Thimme, R.; Blum, H.E.; Zoulim, F. Hepatitis C virus-induced hepatocarcinogenesis. J. Hepatol. 2009, 51, 810-820. [CrossRef] 
19. Joo, M.; Hahn, Y.S.; Kwon, M.; Sadikot, R.T.; Blackwell, T.S.; Christman, J.W. Hepatitis C virus core protein suppresses NF-kappaB activation and cyclooxygenase-2 expression by direct interaction with IkappaB kinase beta. J. Virol. 2005, 79, 7648-7657. [CrossRef]

20. Seitz, H.K.; Simanowski, U.A.; Garzon, F.T.; Rideout, J.M.; Peters, T.J.; Koch, A.; Berger, M.R.; Einecke, H.; Maiwald, M. Possible role of acetaldehyde in ethanol-related rectal cocarcinogenesis in the rat. Gastroenterology 1990, 98, 406-413. [CrossRef]

21. Bradford, B.U.; Kono, H.; Isayama, F.; Kosyk, O.; Wheeler, M.D.; Akiyama, T.E.; Bleye, L.; Krausz, K.W.; Gonzalez, F.J.; Koop, D.R.; et al. Cytochrome P450 CYP2E1, but not nicotinamide adenine dinucleotide phosphate oxidase, is required for ethanol-induced oxidative DNA damage in rodent liver. Hepatology 2005, 41, 336-344. [CrossRef] [PubMed]

22. Theruvathu, J.A.; Jaruga, P.; Nath, R.G.; Dizdaroglu, M.; Brooks, P.J. Polyamines stimulate the formation of mutagenic 1, N2-propanodeoxyguanosine adducts from acetaldehyde. Nucleic Acids Res. 2005, 33, 3513-3520. [CrossRef] [PubMed]

23. Nahon, P.; Sutton, A.; Rufat, P.; Ziol, M.; Akouche, H.; Laguillier, C.; Charnaux, N.; Ganne-Carrié, N.; Grando-Lemaire, V.; N'Kontchou, G.; et al. Myeloperoxidase andm superoxide dismutase 2 polymorphisms comodulate the risk of hepatocellular carcinoma and death in alcoholic cirrhosis. Hepatology 2009, 50, 1484-1493. [CrossRef] [PubMed]

24. Meyerson, M.; Gabriel, S.; Getz, G. Advances in understanding cancer genomes through second-generation sequencing. Nat. Rev. Genet. 2010, 11, 685-696. [CrossRef]

25. Llovet, J.M.; Villanueva, A.; Lachenmayer, A.; Finn, R.S. Advances in targeted therapies for hepatocellular carcinoma in the genomic era. Nat. Rev. Clin. Oncol. 2015, 12, 408-424. [CrossRef] [PubMed]

26. Guichard, C.; Amaddeo, G.; Imbeaud, S.; Ladeiro, Y.; Pelletier, L.; Maad, I.B.; Calderaro, J.; Bioulac-Sage, P.; Letexier, M.; Degos, F.; et al. Integrated analysis of somatic mutations and focal copy-number changes identifies key genes and pathways in hepatocellular carcinoma. Nat. Genet. 2012, 44, 694-698. [CrossRef]

27. Sawey, E.T.; Chanrion, M.; Cai, C.; Wu, G.; Zhang, J.; Zender, L.; Zhao, A.; Busuttil, R.W.; Yee, H.; Stein, L.; et al. Identification of a therapeutic strategy targeting amplified FGF19 in liver cancer by oncogenomic screening. Cancer Cell 2011, 19, 347-358. [CrossRef]

28. Cleary, S.P.; Jeck, W.R.; Zhao, X.; Chen, K.; Selitsky, S.R.; Savich, G.L.; Tan, T.X.; Wu, M.C.; Getz, G.; Lawrence, M.S.; et al. Identification of driver genes in hepatocellular carcinoma by exome sequencing. Hepatology 2013, 58, 1693-1702. [CrossRef]

29. Chen, W.; Jiang, J.; Wang, P.P.; Gong, L.; Chen, J.; Du, W.; Bi, K.; Diao, H. Identifying hepatocellular carcinoma driver genes by integrative pathway crosstalk and protein interaction network. DNA Cell Biol. 2019, 38, 1112-1124. [CrossRef]

30. Hou, J.; Zhang, H.; Sun, B.; Karin, M. The immunobiology of hepatocellular carcinoma in humans and mice: Basic concepts and therapeutic implications. J. Hepatol. 2020, 72, 167-182. [CrossRef]

31. Liao, H.; Chen, W.; Dai, Y.; Richardson, J.J.; Guo, J.; Yuan, K.; Zeng, Y.; Xie, K. Expression of programmed cell death-ligands in hepatocellular carcinoma: Correlation with immune microenvironment and survival outcomes. Front. Oncol. 2019, 9, 883. [CrossRef] [PubMed]

32. European Association for the Study of the Liver; European Organisation for Research and Treatment of Cancer. EASL-EORTC clinical practice guidelines: Management of hepatocellular carcinoma. J. Hepatol. 2012, 56, 908-943. [CrossRef] [PubMed]

33. Sangro, B.; Gomez-Martin, C.; de la Mata, M.; Inarrairaegui, M.; Garralda, E.; Barrera, P.; Riezu-Boj, J.I.; Larrea, E.; Alfaro, C.; Sarobe, P.; et al. A clinical trial of CTLA-4 blockade with tremelimumab in patients with hepatocellular carcinoma and chronic hepatitis C. J. Hepatol. 2013, 59, 81-88. [CrossRef] [PubMed]

34. Le, D.T.; Uram, J.N.; Wang, H.; Bartlett, B.R.; Kemberling, H.; Eyring, A.D.; Skora, A.D.; Luber, B.S.; Azad, N.S.; Laheru, D.; et al. PD-1 blockade in tumors with mismatch-repair deficiency. N. Engl. J. Med. 2015, 372, 2509-2520. [CrossRef]

35. Snyder, A.; Makarov, V.; Merghoub, T.; Yuan, J.; Zaretsky, J.M.; Desrichard, A.; Walsh, L.A.; Postow, M.A.; Wong, P.; Ho, T.S.; et al. Genetic basis for clinical response to CTLA-4 blockade in melanoma. N. Engl. J. Med. 2014, 371, 2189-2199. [CrossRef]

36. Larkin, J.; Chiarion-Sileni, V.; Gonzalez, R.; Grob, J.J.; Cowey, C.L.; Lao, C.D.; Schadendorf, D.; Dummer, R.; Smylie, M.; Rutkowski, P.; et al. Combined nivolumab and ipilimumab or monotherapy in untreated melanoma. N. Engl. J. Med. 2015, 373, 23-34. [CrossRef] 
37. Borghaei, H.; Paz-Ares, L.; Horn, L.; Spigel, D.R.; Steins, M.; Ready, N.E.; Chow, L.Q.; Vokes, E.E.; Felip, E.; Holgado, E.; et al. Nivolumab versus docetaxel in advanced nonsquamous non-small-cell lung cancer. N. Engl. J. Med. 2015, 373, 1627-1639. [CrossRef]

38. Iannacone, M.; Sitia, G.; Isogawa, M.; Marchese, P.; Castro, M.G.; Lowenstein, P.R.; Chisari, F.V.; Ruggeri, Z.M.; Guidotti, L.G. Platelets mediate cytotoxic T lymphocyte-induced liver damage. Nat. Med. 2005, 11, 1167-1169. [CrossRef]

39. Carr, B.I.; Lin, C.Y.; Lu, S.N. Platelet-related phenotypic patterns in hepatocellular carcinoma patients. Semin. Oncol. 2014, 41, 415-421. [CrossRef]

40. Carr, B.I.; Guerra, V. Thrombocytosis and hepatocellular carcinoma. Dig. Dis. Sci. 2013, 58, 1790-1796. [CrossRef]

41. Leslie, M. Cell biology. Beyond clotting: The powers of platelets. Science 2010, 328, 562-564. [CrossRef] [PubMed]

42. Borsig, L. The role of platelet activation in tumor metastasis. Expert Rev. Anticancer Ther. 2008, 8, 1247-1255. [CrossRef] [PubMed]

43. Matsuo, R.; Nakano, Y.; Ohkohchi, N. Platelet administration via the portal vein promotes liver regeneration in rats after 70\% hepatectomy. Ann. Surg. 2011, 253, 759-763. [CrossRef] [PubMed]

44. Yu, Y.; Zhou, X.D.; Liu, Y.K.; Ren, N.; Chen, J.; Zhao, Y. Platelets promote the adhesion of human hepatoma cells with a highly metastatic potential to extracellular matrix protein: Involvement of platelet P-selectin and GP Ilb-IIIa. J. Cancer Res. Clin. Oncol. 2002, 128, 283-287.

45. Lalor, P.F.; Herbert, J.; Bicknell, R.; Adams, D.H. Hepatic sinusoidal endothelium avidly binds platelets in an integrin-dependent manner, leading to platelet and endothelial activation and leukocyte recruitment. Am. J. Physiol. Gastrointest. Liver Physiol. 2013, 304, G469-G478. [CrossRef]

46. Shetty, S.; Lalor, P.F.; Adams, D.H. Liver sinusoidal endothelial cells-Gatekeepers of hepatic immunity. Nat. Rev. Gastroenterol. Hepatol. 2018, 15, 555-567. [CrossRef]

47. Pancoska, P.; Carr, B.I. Macro-and micro-environmental factors in clinical hepatocellular cancer. Semin. Oncol. 2014, 41, 185-194. [CrossRef]

48. D'Alessandro, R.; Messa, C.; Refolo, M.G.; Carr, B.I. Modulation of sensitivity and resistance to multikinase inhibitors by microenvironmental platelet factors in HCC. Expert Opin. Pharm. 2015, 16, 2773-2780. [CrossRef]

49. D'Alessandro, R.; Refolo, M.G.; Lippolis, C.; Carella, N.; Messa, C.; Cavallini, A.; Carr, B.I. Modulation of regorafenib effects on HCC cell lines by epidermal growth factor. Cancer Chemother. Pharm. 2015, 75, 1237-1245. [CrossRef]

50. Lippolis, C.; Refolo, M.G.; D'Alessandro, R.; Carella, N.; Messa, C.; Cavallini, A.; Carr, B.I. Resistance to multikinase inhibitor actions mediated by insulin like growth factor-1. J. Exp. Clin. Cancer Res. 2015, 34, 90. [CrossRef]

51. Nault, J.C.; Ningarhari, M.; Rebouissou, S.; Zucman-Rossi, J. The role of telomeres and telomerase in cirrhosis and liver cancer. Nat. Rev. Gastroenterol. Hepatol. 2019, 16, 544-558. [CrossRef] [PubMed]

52. Youssef, N.; Paradis, V.; Ferlicot, S.; Bedossa, P. In situ detection of telomerase enzymatic activity in human hepatocellular carcinogenesis. J. Pathol. 2001, 194, 459-465. [CrossRef] [PubMed]

53. Nault, J.C.; Calderaro, J.; Di Tommaso, L.; Balabaud, C.; Zafrani, E.S.; Bioulac-Sage, P.; Roncalli, M.; Zucman-Rossi, J. Telomerase reverse transcriptase promoter mutation is an early somatic genetic alteration in the transformation of premalignant nodules in hepatocellular carcinoma on cirrhosis. Hepatology 2014, 60, 1983-1992. [CrossRef] [PubMed]

54. He, G.; Dhar, D.; Nakagawa, H.; Font-Burgada, J.; Ogata, H.; Jiang, Y.; Shalapour, S.; Seki, E.; Yost, S.E.; Jepsen, K.; et al. Identification of Liver Cancer Progenitors Whose Malignant Progression Depends on Autocrine IL-6 Signaling. Cell 2013, 155, 384-396. [CrossRef] [PubMed]

55. Kang, T.W.; Yevsa, T.; Woller, N.; Hoenicke, L.; Wuestefeld, T.; Dauch, D.; Hohmeyer, A.; Gereke, M.; Rudalska, R.; Potapova, A.; et al. Senescence surveillance of pre-malignant hepatocytes limits liver cancer development. Nature 2011, 479, 547-551. [CrossRef]

56. Kim, A.K.; Dziura, J.; Strazzabosco, M. Nonsteroidal anti-inflammatory drug use, chronic liver disease, and hepatocellular carcinoma: The egg of Columbus or another illusion? Hepatology 2013, 58, 819-821. [CrossRef]

57. Cervello, M.; Montalto, G. Cyclooxygenases in hepatocellular carcinoma. World J. Gastroenterol. 2006, 12, 5113-5121. [CrossRef] 
58. Tao, Y.; Li, Y.; Liu, X.; Deng, Q.; Yu, Y.; Yang, Z. Nonsteroidal anti-inflammatory drugs, especially aspirin, are linked to lower risk and better survival of hepatocellular carcinoma: A meta-analysis. Cancer Manag. Res. 2018, 10, 2695-2709. [CrossRef]

59. Zhang, H.L.; Wang, M.D.; Zhou, X.; Qin, C.J.; Fu, G.B.; Tang, L.; Wu, H.; Huang, S.; Zhao, L.H.; Zeng, M.; et al. Blocking preferential glucose uptake sensitizes liver tumor-initiating cells to glucose restriction and sorafenib treatment. Cancer Lett. 2017, 388, 1-11. [CrossRef]

60. Cai, H.; Zhu, X.D.; Ao, J.Y.; Ye, B.G.; Zhang, Y.Y.; Chai, Z.T.; Wang, C.H.; Shi, W.K.; Cao, M.Q.; Li, X.L.; et al. Colony-stimulating factor-1-induced AIF1 expression in tumorassociated macrophages enhances the progression of hepatocellular carcinoma. Oncoimmunology 2017, 6, e1333213. [CrossRef]

61. Loo, T.M.; Kamachi, F.; Watanabe, Y.; Yoshimoto, S.; Kanda, H.; Arai, Y.; Nakajima-Takagi, Y.; Iwama, A.; Koga, T.; Sugimoto, Y.; et al. Gut microbiota promotes obesity-associated liver cancer through PGE2-mediated suppression of antitumor immunity. Cancer Discov. 2017, 7, 522-538. [CrossRef] [PubMed]

62. Yoshimoto, S.; Loo, T.M.; Atarashi, K.; Kanda, H.; Sato, S.; Oyadomari, S.; Iwakura, Y.; Oshima, K.; Morita, H.; Hattori, M.; et al. Obesity-induced gut microbial metabolite promotes liver cancer through senescence secretome. Nature 2013, 499, 97-101. [CrossRef] [PubMed]

63. Deng, Z.B.; Zhuang, X.; Ju, S.; Xiang, X.; Mu, J.; Liu, Y.; Jiang, H.; Zhang, L.; Mobley, J.; McClain, C.; et al. Exosome-like nanoparticles from intestinal mucosal cells carry prostaglandin E2 and suppress activation of liver NKT cells. J. Immunol. 2013, 190, 3579-3589. [CrossRef] [PubMed]

64. Yang, L.; Inokuchi, S.; Roh, Y.S.; Song, J.; Loomba, R.; Park, E.J.; Seki, E. Transforming growth factor-beta signaling in hepatocytes promotes hepatic fibrosis and carcinogenesis in mice with hepatocyte-specific deletion of TAK1. Gastroenterology 2013, 144, 1042-1054. [CrossRef] [PubMed]

65. Yan, W.; Liu, X.; Ma, H.; Zhang, H.; Song, X.; Gao, L.; Liang, X.; Ma, C. Tim-3 fosters HCC development by enhancing TGF-beta-mediated alternative activation of macrophages. Gut 2015, 64, 1593-1604. [CrossRef]

66. Puche, J.E.; Saiman, Y.; Friedman, S.L. Hepatic stellate cells and liver fibrosis. Compr. Physiol. 2013, 3, 1473-1492.

67. Park, S.-A.; Kim, M.-J.; Park, S.-Y.; Kim, J.-S.; Lim, W.; Nam, J.-S.; Sheen, Y.Y. TIMP-1 mediatesTGF-dependent crosstalk between hepatic stellate and cancer cells via FAK signaling. Sci. Rep. 2015, 5, 16492. [CrossRef]

68. Dituri, F.; Cossu, C.; Mancarella, S.; Giannelli, G. The Interactivity between TGF and BMP signaling in organogenesis, fibrosis, and cancer. Cells 2019, 8, 1130. [CrossRef]

69. Yu, L.X.; Ling, Y.; Wang, H.Y. Role of non-resolving inflammation in hepatocellular carcinoma development and progression. npj Precis. Oncol. 2018, 2, 6. [CrossRef]

70. Ikeda, E.; Achen, M.G.; Breier, G.; Risau, W. Hypoxia-induced transcriptional activation and increased mRNA stability of vascular endothelial growth factor in C6 glioma cells. J. Biol. Chem. 1995, 270, 19761-19766. [CrossRef]

71. Forsythe, J.A.; Jiang, B.H.; Iyer, N.V.; Agani, F.; Leung, S.W.; Koos, R.D.; Semenza, G.L. Activation of vascular endothelial growth factor gene transcription by hypoxia-inducible factor 1. Mol. Cell. Biol. 1996, 16, 4604-4613. [CrossRef] [PubMed]

72. Jain, R.K. Normalization of tumor vasculature: An emerging concept in antiangiogenic therapy. Science 2005, 307, 58-62. [CrossRef] [PubMed]

73. Yu, D.C.; Chen, J.; Ding, Y.T. Hypoxic and highly angiogenic non-tumor tissues surrounding hepatocellular carcinoma: The "niche" of endothelial progenitor cells. Int. J. Mol. Sci. 2010, 11, 2901-2909. [CrossRef] [PubMed]

74. Lin, C.A.; Chang, L.L.; Zhu, H.; He, Q.J.; Yang, B. Hypoxic microenvironment and hepatocellular carcinoma treatment. Hepatoma Res. 2018, 4, 26. [CrossRef]

75. Chouaib, S.; Noman, M.Z.; Kosmatopoulos, K.; Curran, M.A. Hypoxic stress: Obstacles and opportunities for innovative immunotherapy of cancer. Oncogene 2017, 36, 439-445. [CrossRef]

76. Choi, S.B.; Park, J.B.; Song, T.J.; Choi, S.Y. Molecular mechanism of HIF-1-independent VEGF expression in a hepatocellular carcinoma cell line. Int. J. Mol. Med. 2011, 28, 449-454.

77. Xiong, X.X.; Qiu, X.Y.; Hu, D.X.; Chen, X.Q. Advances in hypoxia-mediated mechanisms in hepatocellular carcinoma. Mol. Pharm. 2017, 92, 246-255. [CrossRef]

78. Guise, C.P.; Mowday, A.M.; Ashoorzadeh, A.; Yuan, R.; Lin, W.H.; Wu, D.H.; Smaill, J.B.; Patterson, A.V.; Ding, K. Bioreductive prodrugs as cancer therapeutics: Targeting tumor hypoxia. Chin. J. Cancer 2014, 33, 80-86. [CrossRef] 
79. Moen, I.; Stuhr, L.E. Hyperbaric oxygen therapy and cancer-A review. Target Oncol. 2012, 7, $233-242$. [CrossRef]

80. Cheng, X.; Zhang, X.; Cheng, W.; Chen, J.; Ma, C.; Yang, B.; Hua, Z.C. Tumor-specific delivery of histidine-rich glycoprotein suppresses tumor growth and metastasis by anti-angiogenesis and vessel normalization. Curr. Gene Ther. 2014, 14, 75-85. [CrossRef]

81. Chen, D.S.; Mellman, I. Oncology meets immunology: The cancer-immunity cycle. Immunity 2013, 39, 1-10. [CrossRef]

82. Cancer Genome Atlas Research Network. Comprehensive and integrative genomic characterization of hepatocellular carcinoma. Cell 2017, 169, 1327-1341. [CrossRef] [PubMed]

83. Qin, L.X. Inflammatory immune responses in tumor microenvironment and metastasis of hepatocellular carcinoma. Cancer Microenviron. 2012, 5, 203-209. [CrossRef] [PubMed]

84. Yang, J.; Zhang, J.X.; Wang, H.; Wang, G.L.; Hu, Q.G.; Zheng, Q.C. Hepatocellular carcinoma and macrophage interaction induced tumor immunosuppression via Treg requires TLR4 signaling. World J. Gastroenterol. 2012, 18, 2938-2947. [CrossRef]

85. Chen, K.J.; Lin, S.Z.; Zhou, L.; Xie, H.Y.; Zhou, W.H.; Taki-Eldin, A.; Zheng, S.S. Selective recruitment of regulatory $\mathrm{T}$ cell through CCR6-CCL20 in hepatocellular carcinoma fosters tumor progression and predicts poor prognosis. PLoS ONE 2011, 6, e24671. [CrossRef] [PubMed]

86. Fu, J.; Xu, D.; Liu, Z.; Shi, M.; Zhao, P.; Fu, B.; Zhang, Z.; Yang, H.; Zhang, H.; Zhou, C.; et al. Increased regulatory $\mathrm{T}$ cells correlate with CD8 T-cell impairment and poor survival in hepatocellular carcinoma patients. Gastroenterology 2007, 132, 2328-2339. [CrossRef]

87. Behboudi, S.; Boswell, S.; Williams, R. Cell-mediated immune responses to alpha-fetoprotein and other antigens in hepatocellular carcinoma. Liver Int. 2010, 30, 521-526. [CrossRef]

88. Deng, Y.; Cheng, J.; Fu, B.; Liu, W.; Chen, G.; Zhang, Q.; Yang, Y. Hepatic carcinoma-associated fibroblasts enhance immune suppression by facilitating the generation of myeloid-derived suppressor cells. Oncogene 2017, 36, 1090-1101. [CrossRef] [PubMed]

89. Nan, J.; Xing, Y.F.; Hu, B.; Tang, J.X.; Dong, H.M.; He, Y.M.; Ruan, D.Y.; Ye, Q.J.; Cai, J.R.; Ma, X.K.; et al. Endoplasmic reticulum stress induced LOX-1(+) CD15(+) polymorphonuclear myeloid-derived suppressor cells in hepatocellular carcinoma. Immunology 2018, 154, 144-155. [CrossRef] [PubMed]

90. Kondo, Y.; Shimosegawa, T. Significant roles of regulatory T cells and myeloid derived suppressor cells in hepatitis B virus persistent infection and hepatitis B virus-related HCCs. Int. J. Mol. Sci. 2015, 16, 3307-3322. [CrossRef]

91. Liu, M.; Zhou, J.; Liu, X.; Feng, Y.; Yang, W.; Wu, F.; Cheung, O.K.; Sun, H.; Zeng, X.; Tang, W. Targeting monocyte-intrinsic enhancer reprogramming improves immunotherapy efficacy in hepatocellular carcinoma. Gut 2019. [CrossRef] [PubMed]

92. Zhang, H.; Li, Z.; Wang, L.; Tian, G.; Tian, J.; Yang, Z.; Cao, G.; Zhou, H.; Zhao, L.; Wu, Z.; et al. Critical role of myeloid-derived suppressor cells in tumor induced liver immune suppression through inhibition of NKT cell function. Front. Immunol. 2017, 8, 129. [CrossRef] [PubMed]

93. Srivastava, M.K.; Sinha, P.; Clements, V.K.; Rodriguez, P.; Ostrand-Rosenberg, S. Myeloid-derived suppressor cells inhibit T-cell activation by depleting cystine and cysteine. Cancer Res. 2010, 70, 68-77. [CrossRef] [PubMed]

94. Dardalhon, V.; Anderson, A.C.; Karman, J.; Apetoh, L.; Chandwaskar, R.; Lee, D.H.; Cornejo, M.; Nishi, N.; Yamauchi, A.; Quintana, F.J.; et al. Tim-3/galectin-9 pathway: Regulation of Th1 immunity through promotion of CD11b+Ly-6G+ myeloid cells. J. Immunol. 2010, 185, 1383-1392. [CrossRef]

95. Hoechst, B.; Voigtlaender, T.; Ormandy, L.; Gamrekelashvili, J.; Zhao, F.; Wedemeye, H.; Lehner, F.; Manns, M.P.; Greten, T.F.; Korangy, F. Myeloid derived suppressor cells inhibit natural killer cells in patients with hepatocellular carcinoma via the NKp30 receptor. Hepatology 2009, 50, 799-807. [CrossRef]

96. Qian, B.Z.; Pollard, J.W. Macrophage diversity enhances tumor progression and metastasis. Cell 2010, 141, 39-51. [CrossRef]

97. Movahedi, K.; Laoui, D.; Gysemans, C.; Baeten, M.; Stangé, G.; Van den Bossche, J.; Mack, M.; Pipeleers, D.; In't Veld, P.; De Baetselier, P.; et al. Different tumor microenvironments contain functionally distinct subsets of macrophages derived from Ly6C(high) monocytes. Cancer Res. 2010, 70, 5728-5739. [CrossRef] [PubMed]

98. Nicolas-Avila, J.A.; Adrover, J.M.; Hidalgo, A. Neutrophils in homeostasis, immunity, and Cancer. Immunity 2017, 46, 15-28. [CrossRef] 
99. Wang, T.T.; Yuan, J.H.; Ma, J.Z.; Yang, W.J.; Liu, X.N.; Yin, Y.P.; Liu, Y.; Pan, W.; Sun, S.H. CTGF secreted by mesenchymal-like hepatocellular carcinoma cells plays a role in the polarization of macrophages in hepatocellular carcinoma progression. BioMed Pharm. 2017, 95, 111-119. [CrossRef]

100. Zhu, Y.; Yang, J.; Xu, D.; Gao, X.M.; Zhang, Z.; Hsu, J.L.; Li, C.W.; Lim, S.O.; Sheng, Y.Y.; Zhang, Y.; et al. Disruption of tumour-associated macrophage trafficking by the osteopontin-induced colony-stimulating factor-1 signalling sensitises hepatocellular carcinoma to anti-PD-L1 blockade. Gut 2019, 68, 1653-1666. [CrossRef]

101. Zhou, J.; Ding, T.; Pan, W.; Zhu, L.Y.; Li, L.; Zheng, L. Increased intratumoral regulatory T cells are related to intratumoral macrophages and poor prognosis in hepatocellular carcinoma patients. Int. J. Cancer 2009, 125, 1640-1648. [CrossRef] [PubMed]

102. Andzinski, L.; Kasnitz, N.; Stahnke, S.; Wu, C.F.; Gereke, M.; von Köckritz-Blickwede, M.; Schilling, B.; Brandau, S.; Weiss, S.; Jablonska, J. Type I IFNs induce anti-tumor polarization of tumor associated neutrophils in mice and human. Int. J. Cancer 2016, 138, 1982-1993. [CrossRef] [PubMed]

103. Michaeli, J.; Shaul, M.E.; Mishalian, I.; Hovav, A.H.; Levy, L.; Zolotriov, L.; Granot, Z.; Fridlender, Z.G. Tumor-associated neutrophils induce apoptosis of nonactivated CD8 T-cells in a TNFalpha and NO-dependent mechanism, promoting a tumor-supportive environment. Oncoimmunology 2017, 6, e1356965. [CrossRef] [PubMed]

104. Chew, V.; Chen, J.; Lee, D.; Loh, E.; Lee, J.; Lim, K.H.; Weber, A.; Slankamenac, K.; Poon, R.T.; Yang, H.; et al. Chemokine-driven lymphocyte infiltration: An early intratumoural event determining long-term survival in resectable hepatocellular carcinoma. Gut 2012, 61, 427-438. [CrossRef]

105. Flecken, T.; Schmidt, N.; Hild, S.; Gostick, E.; Drognitz, O.; Zeiser, R.; Schemmer, P.; Bruns, H.; Eiermann, T.; Price, D.A.; et al. Immunodominance and functional alterations of tumor-associated antigen specific CD8+ T-cell responses in hepatocellular carcinoma. Hepatology 2014, 59, 1415-1426. [CrossRef]

106. Kurebayashi, Y.; Ojima, H.; Tsujikawa, H.; Kubota, N.; Maehara, J.; Abe, Y.; Kitago, M.; Shinoda, M.; Kitagawa, Y.; Sakamoto, M. Landscape of immune microenvironment in hepatocellular carcinoma and its additional impact on histological and molecular classification. Hepatology 2018, 68, 1025-1041. [CrossRef]

107. Zhou, S.L.; Zhou, Z.J.; Hu, Z.Q.; Huan, X.W.; Wang, Z.; Chen, E.B.; Fan, J.; Cao, Y.; Dai, Z.; Zhou, J. Tumor-associated neutrophils recruit macrophages and $\mathrm{T}$ regulatory cells to promote progression of hepatocellular carcinoma and resistance to Sorafenib. Gastroenterology 2016, 150, 1646-1658. [CrossRef]

108. Quan, H.; Zhou, F.; Nie, D.; Chen, Q.; Cai, X.; Shan, X.; Zhou, Z.; Chen, K.; Huang, A.; Li, S.; et al. Hepatitis $C$ virus core protein epigenetically silences SFRP1 and enhances HCC aggressiveness by inducing epithelial-mesenchymal transition. Oncogene 2013. [CrossRef]

109. Turati, F.; Trichopoulos, D.; Polesel, J.; Bravi, F.; Rossi, M.; Talamini, R.; Franceschi, S.; Montella, M.; Trichopoulou, A.; La Vecchia, C.; et al. Mediterranean diet and hepatocellular carcinoma. J. Hepatol. 2014, 60, 606-611. [CrossRef]

110. Fox, J.G.; Feng, Y.; Theve, E.J.; Raczynski, A.R.; Fiala, J.L.; Doernte, A.L.; Williams, M.; McFaline, J.L.; Essigmann, J.M.; Schauer, D.B.; et al. Gut microbes define liver cancer risk in mice exposed to chemical and viral transgenic hepatocarcinogens. Gut 2010, 59, 88-97. [CrossRef]

111. Lv, L.H.; Wan, Y.L.; Lin, Y.; Zhang, W.; Yang, M.; Li, G.L.; Lin, H.M.; Shang, C.Z.; Chen, Y.J.; Min, J. Anticancer drugs cause release of exosomes with heat shock proteins from human hepatocellular carcinoma cells that elicit effective natural killer cell antitumor responses in vitro. J. Biol. Chem. 2012, 287, 15874-15885. [CrossRef] [PubMed]

112. Ma, C.; Han, M.; Heinrich, B.; Fu, Q.; Zhang, Q.; Sandhu, M.; Agdashian, D.; Terabe, M.; Berzofsky, J.A.; Fako, V; et al. Gut microbiome-mediated bile acid metabolism regulates liver cancer via NKT cells. Science 2018, 360. [CrossRef] [PubMed]

113. Bridget, P.; Fong, K.L.; Kelley, R.K. Immunotherapy in hepatocellular carcinoma: The complex interface between inflammation, fibrosis, and the immune response. J. Immunother. Cancer 2019, 7, 267.

114. Homann, C.; Varming, K.; Hogase, K.; Mollnes, T.E.; Graudal, N.; Thomsen, A.C.; Garred, P. Acquired C3 deficiency in patients with alcoholic cirrhosis predisposes to infection and increased mortality. Gut 1997, 40, 544-549. [CrossRef]

115. Homann, C.; Garred, P.; Hasselqvist, P.; Graudal, N.; Thiel, S.; Thomsen, A.C. Mannan-binding protein and complement dependent opsonization in alcoholic cirrhosis. Liver 1995, 15, 39-44. [CrossRef] [PubMed] 
116. Chew, V.; Lai, L.; Pan, L.; Lim, C.J.; Li, J.; Ong, R.; Chua, C.; Leong, J.Y.; Lim, K.H.; Toh, H.C.; et al. Delineation of an immunosuppressive gradient in hepatocellular carcinoma using highdimensional proteomic and transcriptomic analyses. Proc. Natl. Acad. Sci. USA 2017, 114, E5900-E5909. [CrossRef]

117. Snelgrove, S.L.; Abeynaike, L.D.; Thevalingam, S.; Deane, A.; Hickey, M.J. Regulatory T Cell Transmigration and Intravascular Migration Undergo Mechanistically Distinct Regulation at Different Phases of the Inflammatory Response. J Immunol. 2019, 203, 2850-2861. [CrossRef]

118. Wu, K.; Kryczek, I.; Chen, L.; Zou, W.; Welling, T.H. Kupffer cell suppression of CD8+ T cells in human hepatocellular carcinoma is mediated by B7-H1/programmed death-1 interactions. Cancer Res. 2009, 69, 8067-8075. [CrossRef]

119. Do, A.L.; Wong, C.R.; Nguyen, L.H.; Nguyen, V.G.; Trinh, H.; Nguyen, M.H. Hepatocellular carcinoma incidence in noncirrhotic patients with chronic hepatitis B and patients with cirrhosis of all etiologies. J. Clin. Gastroenterol. 2014, 48, 644-649. [CrossRef]

120. Kao, J.H.; Chen, P.J.; Lai, M.Y.; Chen, D.S. Basal core promoter mutations of hepatitis B virus increase the risk of hepatocellular carcinoma in hepatitis B carriers. Gastroenterology 2003, 124, 327-334. [CrossRef]

121. Reig, M.; Marino, Z.; Perello, C.; Inarrairaegui, M.; Ribeiro, A.; Lens, S.; Díaz, A.; Vilana, R.; Darnell, A.; Varela, M.; et al. Unexpected high rate of early tumor recurrence in patients with HCV-related HCC undergoing interferon-free therapy. J. Hepatol. 2016, 65, 719-726. [CrossRef] [PubMed]

122. Nirei, K.; Kanda, T.; Nakamura, H.; Matsuoka, S.; Takayama, T.; Sugitani, M.; Moriyama, M. Persistent hepatic inflammation plays a role in hepatocellular carcinoma after sustained virological response in patients with HCV infection. Int. J. Med. Sci. 2018, 15, 466-474. [CrossRef] [PubMed]

123. Kitaoka, S.; Shiota, G.; Kawasaki, H. Serum levels of interleukin-10, interleukin-12 and soluble interleukin-2 receptor in chronic liver disease type C. Hepatogastroenterology 2003, 50, 1569-1574.

124. Huang, Y.S.; Hwang, S.J.; Chan, C.Y.; Wu, J.C.; Chao, Y.; Chang, F.Y.; Lee, S.D. Serum levels of cytokines in hepatitis C-related liver disease: A longitudinal study. Zhonghua Yi Xue Za Zhi (Taipei) 1999, 62, 327-333. [PubMed]

125. Song, L.H.; Binh, V.Q.; Duy, D.N.; Kun, J.F.; Bock, T.C.; Kremsner, P.G.; Luty, A.J. Serum cytokine profiles associated with clinical presentation in Vietnamese infected with hepatitis B virus. J. Clin. Virol. 2003, 28, 93-103. [CrossRef]

126. Lim, C.J.; Lee, Y.H.; Pan, L.; Lai, L.; Chua, C.; Wasser, M.; Lim, T.K.H.; Yeong, J.; Toh, H.C.; Lee, S.Y.; et al. Multidimensional analyses reveal distinct immune microenvironment in hepatitis B virus related hepatocellular carcinoma. Gut 2019, 68, 916-927. [CrossRef] [PubMed]

127. Hwang, I.C.; Chang, J.; Kim, K.; Park, S.M. Aspirin use and risk of hepatocellular carcinoma in a national cohort study of Korean adults. Sci. Rep. 2018, 8, 4968. [CrossRef]

128. Hernandez-Vargas, H.; Lambert, M.P.; Le Calvez-Kelm, F.; Gouysse, G.; McKayChopin, S.; Tavtigian, S.V.; Scoazec, J.Y.; Herceg, Z. Hepatocellular carcinoma displays distinct DNA methylation signatures with potential as clinical predictors. PLoS ONE 2010, 5, e9749. [CrossRef]

129. Sia, D.; Jiao, Y.; Martinez-Quetglas, I.; Kuchuk, O.; Villacorta-Martin, C.; Castro de Moura, M.; Putra, J.; Camprecios, G.; Bassaganyas, L.; Akers, N.; et al. Identification of an immune-specific class of hepatocellular carcinoma, based on molecular features. Gastroenterology 2017, 153, 812-826. [CrossRef]

130. Boutari, C.; Perakakis, N.; Mantzoros, C.S. Association of adipokines with development and progression of nonalcoholic fatty liver disease. Endocrinol. Metab. (Seoul) 2018, 33, 33-43. [CrossRef]

131. Haas, J.T.; Vonghia, L.; Mogilenko, D.A.; Verrijken, A.; Molendi-Coste, O.; Fleury, S.; Deprince, A.; Nikitin, A.; Woitrain, E.; Ducrocq-Geoffroy, L.; et al. Transcriptional network analysis implicates altered hepatic immune function in NASH development and resolution. Nat. Metab. 2019, 1, 604-614. [CrossRef] [PubMed]

132. Shalapour, S.; Lin, X.J.; Bastian, I.N.; Brain, J.; Burt, A.D.; Aksenov, A.A.; Vrbanac, A.F.; Li, W.; Perkins, A.; Matsutani, T.; et al. Inflammation-induced IgA+ cells dismantle anti-liver cancer immunity. Nature 2017, 551, 340-345. [CrossRef]

133. Chen, Y.; Ramjiawan, R.R.; Reiberger, T.; Ng, M.R.; Hato, T.; Huang, Y.; Ochiai, H.; Kitahara, S.; Unan, E.C.; Reddy, T.P.; et al. CXCR4 inhibition in tumor microenvironment facilitates anti-programmed death receptor-1 immunotherapy in sorafenib-treated hepatocellular carcinoma in mice. Hepatology 2015, 61, 1591-1602. [CrossRef] [PubMed] 
134. Brown, Z.J.; Yu, S.J.; Heinrich, B.; Ma, C.; Fu, Q.; Sandhu, M.; Agdashian, D.; Zhang, Q.; Korangy, F.; Greten, T.F. Indoleamine 2,3-dioxygenase provides adaptive resistance to immune checkpoint inhibitors in hepatocellular carcinoma. Cancer Immunol. Immunother. 2018, 67, 1305-1315. [CrossRef] [PubMed]

135. Kimura, T.; Kato, Y.; Ozawa, Y.; Kodama, K.; Ito, J.; Ichikawa, K.; Yamada, K.; Hori, Y.; Tabata, K.; Takase, K.; et al. Immunomodulatory activity of Lenvatinib contributes to antitumor activity in the Hepa1-6 hepatocellular carcinoma model. Cancer Sci. 2018, 109, 3993-4002. [CrossRef] [PubMed]

136. Llopiz, D.; Ruiz, M.; Villanueva, L.; Iglesias, T.; Silva, L.; Egea, J.; Lasarte, J.J.; Pivette, P.; Trochon-Joseph, V.; Vasseur, B.; et al. Enhanced anti-tumor efficacy of checkpoint inhibitors in combination with the histone deacetylase inhibitor Belinostat in a murine hepatocellular carcinoma model. Cancer Immunol. Immunother. 2019, 68, 379-393. [CrossRef] [PubMed]

137. Wen, L.; Xin, B.; Wu, P.; Lin, C.H.; Peng, C.; Wang, G.; Lee, J.; Lu, L.F.; Feng, G.S. An efficient combination immunotherapy for primary liver cancer by harmonized activation of innate and adaptive immunity in mice. Hepatology 2019, 69, 2518-2532. [CrossRef] [PubMed]

138. Yu, S.J.; Ma, C.; Heinrich, B.; Brown, Z.; Sandhu, M.; Zhang, Q.; Fu, Q.; Agdashian, D.; Rosato, U.; Korangy, F.; et al. Targeting the crosstalk between cytokine-induced killer cells and myeloid-derived suppressor cells in hepatocellular carcinoma. J. Hepatol. 2019, 70, 449-457. [CrossRef]

139. Liu, Z.; Lu, Z.; Jing, R.; Zuo, B.; Gao, X.; Han, G.; Qi, H.; Wu, L.; Liu, Y.; Yin, H. Alarmin augments the antitumor immunity of lentiviral vaccine in ectopic, orthotopic and autochthonous hepatocellular carcinoma mice. Theranostic 2019, 9, 4006-4018. [CrossRef]

140. Liu, H.; Xu, Y.; Xiang, J.; Long, L.; Green, S.; Yang, Z.; Zimdahl, B.; Lu, J.; Cheng, N.; Horan, L.H.; et al. Targeting alpha-fetoprotein (AFP)-MHC complex with CAR T-cell therapy for liver cancer. Clin. Cancer Res. 2017, 23, 478-488. [CrossRef]

141. Batra, S.A.; Rathi, P.; Guo, L.; Courtney, A.N.; Fleurence, J.; Balzeau, J.; Shaik, R.S.; Nguyen, T.P.; Wu, M.F.; Bulsara, S.; et al. Glypican-3-specific CAR T cells co-expressing IL15 and IL21 have superior expansion and antitumor activity against hepatocellular carcinoma. Cancer Immunol. Res. 2020, 8, 309-320. [CrossRef] [PubMed]

142. Abou-Alfa, G.K.; Chan, S.L.; Furuse, J.; Galle, P.R.; Kelley, R.K.; Qin, S.; Armstrong, J.; Darilay, A.; Vlahovic, G.; Negro, A.; et al. A randomized, multicenter phase 3 study of durvalumab (D) and tremelimumab (T) as first-line treatment in patients with unresectable hepatocellular carcinoma (HCC): HIMALAYA study. J. Clin. Oncol. 2018, 36. [CrossRef] 